\title{
Multinational enterprises and corporate tax planning: a review of literature and suggestions for a future research agenda
}

Article

Accepted Version

Creative Commons: Attribution-Noncommercial-No Derivative Works 4.0

Cooper, M. and Nguyen, Q. (2020) Multinational enterprises and corporate tax planning: a review of literature and suggestions for a future research agenda. International Business Review, 29 (3). 101692. ISSN 0969-5931 doi: https://doi.org/10.1016/j.ibusrev.2020.101692 Available at https://centaur.reading.ac.uk/89207/

It is advisable to refer to the publisher's version if you intend to cite from the work. See Guidance on citing.

To link to this article DOI: http://dx.doi.org/10.1016/j.ibusrev.2020.101692

Publisher: Elsevier

All outputs in CentAUR are protected by Intellectual Property Rights law, including copyright law. Copyright and IPR is retained by the creators or other copyright holders. Terms and conditions for use of this material are defined in the End User Agreement.

www.reading.ac.uk/centaur 
Central Archive at the University of Reading

Reading's research outputs online 


\title{
Multinational enterprises and corporate tax planning: A review of literature and suggestions for a future research agenda
}

\begin{abstract}
Corporate tax planning by the multinational enterprise (MNE), that is, the MNE's ability to plan its tax affairs by using a multitude of strategies to reduce its tax bills legally, is a central research question in the literatures of international business, public economics, tax, finance, law and accounting. Underlying theoretical assumptions, approaches to empirical testing, profit shifting estimation strategies and findings are varied. Thus, it is important to conduct a critical literature review. In this paper, we offer new insights by studying the phenomenon from the international business (IB) perspective. We survey the academic literature on the MNE and corporate tax planning to examine the extent of knowledge on this topic and identify areas that we hope will stimulate interest among IB scholars for further research. We find materials across disciplines that are relevant to IB readers. We examine 120 articles in 51 scholarly journals and classic books published during the period 1966-2017. We identify the key mechanisms and the firm characteristics that may influence corporate tax planning. We suggest a research agenda where IB research can make clear contributions.
\end{abstract}

Key words: multinational enterprise (MNE) and international taxation; corporate tax planning; profit shifting; income shifting; tax avoidance. 


\section{Multinational enterprises and corporate tax planning: A review of literature and suggestions for a future research agenda}

\section{INTRODUCTION}

Tax affects every business, for many companies, including multinational enterprises (MNEs), it is the single largest bill that they will pay each year. Where investments are made, how much is invested, how that investment is funded and where profits are recorded will all be influenced by the tax rates and tax systems faced by the MNE. Without an understanding of how tax can, and does, influence corporate behaviour, our understanding of the motivations, actions and strategies employed by MNEs is incomplete.

MNEs are able to plan their tax affairs by using a multitude of strategies to reduce their tax legally, which is known as "tax planning". The term "tax planning" has recently become more widely used and is intended to encompass the broad range of activities undertaken by firms implementing a strategic approach to reducing their tax bill whilst staying within the bounds of what is legally acceptable. Many previous studies use the term "tax avoidance", defined as the arrangements of their financial affairs to minimize their tax liability within the law. The terms "tax planning" and "tax avoidance" tend to be used interchangeably in the literature. We discuss definitions in more detail in the section below, Methodology.

The literature has also used the terms "profit shifting" and "income shifting". Profit and income shifting refer to the ability of MNEs to shift profits or income from higher to lower tax jurisdictions, thus eroding the tax base of the higher tax jurisdictions as outlined in the OECD's Base Erosion and Profit Shifting (BEPS) work (OECD, 2019). Booking a greater share of their profits in low tax jurisdictions will consequently lead to a lower overall tax burden (Samuelson, 1982; Rugman \& Eden, 1985; Zucman, 2014). Furthermore, tax competition between countries has intensified in recent years as countries compete to attract inward foreign direct investment 
(FDI) (Devereaux, Lockwood \& Redoano, 2008; Altshuler \& Grubert, 2006). Tax rates have fallen across the OECD countries, which, combined with the continued availability of tax havens and/or Offshore Financial Centres (OFCs) have increased the opportunities for MNEs to profit shift. Tax havens are defined as jurisdictions that offer the MNE a low or zero tax rate, stimulating MNEs to locate businesses there and thus reduce overall tax payments globally (Rugman \& Collinson, 2012). Offshore Financial Centres (OFCs) or "conduits" refer to attractive intermediate destinations to transfer capital to other countries via the use of holding companies to manage interest payments or dividends without triggering taxation (Weyzig, 2013).

At the same time, for operational reasons, global value chains have become increasingly long and complex due to the organization of MNE activities (Strange \& Humphrey, 2018; Strange \& Zucchella, 2018). The rise of the digital economy and the multiplicity of locations used by MNEs provide more opportunities for profit shifting (Contractor, 2016a, b; Eden, 2016; Foss, Mudambi \& Murtinu, 2019; McGauhey \& Raimondos, 2019; Nebus, 2019; Ting \& Gray, 2019). As a consequence, corporate taxation and tax avoidance have been the focus of work from governments, international organisations and non-governmental organisations (NGOs) since the global financial crisis of 2008. Fiscal tightening after the financial crisis forced governments to review the revenues that they received and this created greater interest in the revenues raised from corporation tax. Despite all these complex developments in business realities, corporate tax planning as a driver of corporate behaviour has not received the attention within the IB literature that it deserves (Nebus, 2016).

The phenomenon has been examined, mainly empirically, in the fields of public economics, international taxation, finance, law and accounting. The different theoretical foundations and approaches to empirical research and estimation of profit shifting using macro and micro level data have produced a mixed set of results. The development of the literatures has accelerated 
to a point that calls for a disciplined and systematic review. Thus, in this paper, we aim to address two central research questions:

1. What is known about the phenomena of MNE tax planning?

2. How can the IB field contribute to extending our knowledge of this phenomenon?

We adopt an international business (IB) perspective in our review, critically assessing and analysing the relevant literature. We survey previous studies across a range of fields and disciplines to identify the drivers of the heterogeneity of approaches towards corporate tax planning. We highlight the existing gaps in knowledge and attempt to focus attention on these issues for future research. One underlying difficulty for researchers, however, is the lack of coherent theory available to draw on.

Our study makes three key contributions to the literature. First, we examine 120 papers in 51 leading journals and classic books published between 1966 and 2017 and provide a systematic review of both theoretical and empirical literature. Whilst we review the extant empirical research, we also report on the existing theories in the IB field that have been used to underpin research and discuss potential avenues where greater theoretical development could add clarity. In this way, our approach differs significantly from previous key literature review papers, such as Dharmapala, (2014); Hanlon \& Heitzman (2010); Riedel (2018), which focus mainly on reviewing the empirical literature but pay little or no attention to reviewing any theoretical development to explain the phenomenon of MNEs and their tax planning. In our literature review, we find that the IB literature focuses mainly on the theory of FDI and motivations in Dunning's eclectic paradigm (Dunning, 1993). We suggest that this theory can be extended to contribute to our understanding of the motivation for MNE tax planning and we indicate areas of interest to researchers in this field. Empirical research that provides direct observations and managerial insights into the motivation behind tax planning, as well as the mechanisms used in tax planning has, remained scarce, particularly from an IB perspective. The literature from 
other disciplines generates an understanding of firms' opportunities to avoid tax but this work is largely empirical, focusing on the ways in which companies are able to shift profits, with little underpinning theory used to explain the phenomenon. By highlighting the relevant areas of IB theory we hope to generate greater interest in extending Dunning's eclectic paradigm, especially the "escape investments" from high tax in home countries, and/or in developing a theoretical framework that considers the interaction of motivations and opportunities in tax planning for MNEs (Cooper and Nguyen, 2019). Our discussion on the necessity of theoretical development underlines one of our original contributions to the literature.

Second, our study provides a systematic review of the most germane extant literature. We consolidate findings from previous studies across domains and disciplines to create a comprehensive assessment, addressing the existing lack of integrated literature. We use an inductive approach and conduct a qualitative content analysis, which enables us to analyse the contents of the literature carefully examining sources, identifying research themes, and making suggestions for methodological refinements. Specifically, we find that the key mechanisms used in MNE corporate tax planning include the potential manipulation of transfer pricing in intra-firm transactions, the use of internal debt in the capital structure, the location of economic activities, the use of tax havens and/or OFCs, the relocation of valuable intangible assets to low tax jurisdiction, and the accumulation of cash holdings in foreign subsidiaries. Furthermore, we also find that some firm characteristics that may affect MNE tax avoidance aggressiveness include the degree of multinationality, size, profitability, the top management team and corporate social responsibility (CSR). We find and explore a variety of empirical testing approaches and conclude that there is a lack of comparative studies and diversity in geographic focus (the majority of primary studies in our review consider US data with a few studies considering European firms). As such, our study extends and updates previous qualitative literature review papers on international taxation (Hanlon \& Heitzman, 2010; 
Riedel, 2018) and our consideration of the work from an IB perspective generates a new understanding about MNEs and their tax planning approaches.

Third, we generate some recommendations for a new research agenda where IB research can make clear and insightful contributions. In this way, we hope that some of the issues that have been identified in our review can be addressed. Specifically, we recommend that future research focus on theoretical extension and/or development, and the refinement of empirical testing through the use of various research methods and the most effective combination of qualitative and quantitative research approaches. We also note some of the specific difficulties with the data used by many quantitative studies and suggest some solutions to overcome challenges to conducting research in this field.

The next section of this paper discusses some of the issues around definitions and measurements and sets out our methodological approach to this literature review. We then discuss some of the key challenges of conducting research in this area. The following sections set out our findings and critically discuss the most salient articles published, summarised in three sections: The State of Research within IB Literature, Scale of Profit Shifting, Mechanisms of Profit Shifting used in Tax Planning, and Heterogeneity of Approaches and Firm Characteristics. The agenda for future research is brought together in the final section, Research Agenda and Conclusions. We have focused on areas we believe are most relevant to IB researchers but we acknowledge that this field is broad and that there are many other issues which could also be relevant but which are beyond the scope of this paper.

\section{METHODOLOGY}

\subsection{Definition of Key Terms}

Whilst a full discussion of the definitions of the key terms is outside the scope of this paper it is important to define them briefly in order to identify the key words for the search of articles 
which were included in the literature review. Tax avoidance is often defined as the "legal" measures taken by companies to reduce their tax bill often using different mechanisms and methods to shift profits/income from high to low tax jurisdictions. In contrast, tax evasion is considered as more extreme "illegal" measures. This simplistic duality does little to explicate the reality of the options facing the modern MNE. The MNE will adopt a strategic posture in relation to its tax planning that positions it on a continuum of possible measures. The MNE's chosen position reflects its understanding of the legality of the stance and the risk that it is prepared to take that a tax authority may challenge them at a later date, potentially resulting in back payments, fines or legal cases (Wall Street Journal, 2006; Financial Times, 2016).

From an accounting perspective, Hanlon and Heitzman (2010, p. 137) define tax avoidance as activity that results in: 'the reduction of explicit taxes.' This definition is broad, encapsulating any activity that reduces the tax bill. Some activities may be undertaken for operational reasons but may still have the effect of reducing the tax bill. For example, a firm may invest in R\&D for reasons of creating competitive advantage; however, under this definition, if the R\&D attracted government tax credits which reduced the tax liability, claiming these would be labelled as a tax avoidance activity.

Tax planning refers to the ability of MNEs to plan and structure their tax affairs involving a range of mechanisms to reduce tax legally. Not all activities undertaken under this heading would be labelled as tax avoidance but the term tends to embrace a range of activities undertaken by a firm implementing a strategic approach to the tax bill. Measures included within tax planning could be straightforward tax avoidance or reduction schemes, or could relate to the timing of payments. The term "tax planning" indicates the strategic nature of tax and the ability of MNEs to exercise discretion over elements of their approach. Corporate tax planning will include measures that focus on the tax payable on annual income but will also 
concentrate on the tax implications of other corporate activities, such as the structure of the business, particularly after mergers and acquisitions (M\&As).

The literature also uses the terms "profit shifting" and "income shifting", to refer to tax avoidance strategies that exploit gaps and mismatches in tax rules to artificially shift profits to low or no-tax locations (OECD, 2019). It is noted that our study focuses on legal tax avoidance/ profit shifting/ income shifting mechanisms used in the MNE tax planning, not tax evasion.

Within the field of IB, work tends to focus on transfer pricing. The transfer price is the price charged to account for related party transactions within the MNE corporate network, including intra-firm trade, intra-firm loans or knowledge flows of intellectual property, such as the use of patents, trademarks, copyrights, etc. between affiliates of the MNE. Rugman $(1980,1981)$ and Vernon (1971) explicitly downplayed the importance of tax-motivated transfer pricing. The issue was highly politicized at the time by high-profile criticisms against corporate internationalization from within and outside the academia (Servan-Schreiber, 1967; Galbraith, 1967 among others).

The manipulation of these transfer prices is, however, one of the key mechanisms historically used by MNEs to shift profits from high to low tax jurisdictions (Lall, 1973; Vaitsos, 1974). Early theoretical work focused on the optimization of transfer prices in relation to tariffs and taxes (Horst, 1971). It is noted that transfer pricing is required to be in compliance with the arm's length pricing standard (OECD, 2010), defined as the price that exists or would exist on the sale of a given product or service between two unrelated firms (Rugman \& Collinson, 2012).

Profit shifting is a tax practice used to take advantage of the differences that exist between statutory tax rates in different jurisdictions. A variant of profit shifting is to move intangible assets to a holding company located in a low tax country and then charge royalties on the use 
of these intangible assets to the operating subsidiaries. This tax practice can be used to shift income or profits to tax havens and/or OFCs. Another related tax practice is to use certain tax havens for treasury operations, centralizing the finance functions in an offshore hub (GarciaBernado, Fichtner, Takes and Heemskerk, 2017). These jurisdictions have laws that facilitate tax avoidance on passive interest income, such as subpart $\mathrm{F}$ income in the US tax system. A further tax reduction practice involves legally structuring a corporation as an "ownership chain" to enable cross border payments without triggering tax (Lewellen \& Robinson, 2013). Internal debt can also be used in the capital structure where the interest payments between group companies function to transfer income.

Other well-known strategies such as the 'Double Irish-Dutch' sandwich use several of these tax practices in combination. Changes in the Irish tax residence rules in 2015, however, marked the end of these schemes (Riedel, 2018). US MNEs have saved tax by failing to repatriate income earned overseas, instead choosing to hold large cash balances outside the US where it is not liable for tax. This has also been changed by the recent reforms of the US tax system in 2017, which lowered the corporate tax rate, aiming to remove or reduce the incentive to stockpile cash in foreign subsidiaries. It is hoped that firms would be encouraged to return a larger share of earned income to the US where it could be spent on capital investments, dividend payments to shareholders, share buybacks, acquisitions and servicing mature debts (Financial Times, 2019).

\subsection{Selection of Database, Journals, Texts, and Analytic Approach}

In order to answer our research questions, we conducted a thorough literature search to locate and analyse the relevant academic publications. We performed the search in an inductive manner, adapting the methodology used by previous researchers (Jormanainen \& Koveshnikov 2012; Nguyen, 2017). The methodology is presented clearly to demonstrate the reliability of the search. 
In order to conduct a comprehensive search for all potentially relevant papers, we made our search using the Scopus database which is the largest abstract and citation database covering peer-reviewed academic literature. We used broad Boolean search terms ("profit shifting" or “income shifting" or "tax avoidance" or "transfer pricing" or "tax planning" and "corporate taxation") to capture all relevant articles. Search terms related to this topic are difficult to define as the language and the focus of papers has changed over time. As discussed above, tax planning is a term that has come into use only relatively recently, with early work focusing instead on transfer pricing. Our search terms therefore include the older term "transfer pricing" as well as the more modern "tax planning”.

We searched for peer-reviewed, full-length academic journal articles published in English with no refinement for date. Peer reviewed articles enabled us to concentrate our attention on thorough, evidence-based work. For the initial sampling of articles for our review we focused on the key phrases of the paper, elements that describe the main focus of a scholarly article. The results of the first search were sizeable, with 1,841 articles published in 430 journals returned. We then refined our search by restricting the journal coverage to those listed in the UK-based Chartered Association of Business School (CABS) Journal Guide 2015. This gave us a total of 51 journals publishing a total of 475 papers on tax published between 1966 and 2017.

For the next screening step, we reviewed carefully the titles, abstracts, key words, introductions, conclusions and journal outlets of the papers. We included conceptual, empirical and literature review papers. In this way, we prioritised the papers that were directly and explicitly related to our research focus on MNEs and corporate tax planning. We removed papers that were less relevant either because their focus was not on MNEs corporate tax or because their scope was extremely narrow, for example, many articles that were included in the search findings focused on value added tax (VAT), goods and services tax or personal 
income tax. During our reading of the remaining papers we noted further references that were not already included in our list and added extra papers that appeared to be relevant and insightful, essentially our search became iterative, with the Scopus search as our starting point. This process identified 114 articles and six (6) classic books from the IB field and one book from the tax field. Classic IB books were particularly useful for our analysis of theoretical perspectives underpinning this literature. In total, this paper covers a total of 120 primary studies which focus on various aspects of MNEs' corporate tax planning. Table 1 reports the names of the publications included and the number of papers from each publication.

\section{Table 1}

We find that the majority of the academic papers are published in economics journals supplemented by tax, accounting, finance and law journals. It is clear that tax avoidance, tax planning and transfer pricing have been the subject of significant academic scrutiny and research, with much of the work published after the year 2000. We find that the focus on corporation tax from within the IB field has been patchy at best. This appears to confirm the argument made by Nebus (2016) that it is difficult for tax research to find its way into mainstream IB journals (Nebus, 2016).

\subsection{Analytical approach}

To analyse these papers, we follow the qualitative approach outlined in Welch, Piekkari, Plakoyiannaki, and Paavilainen-Maentymaeki (2011). First, we focus on the content of each paper (Suddaby and Greenwood, 2005). We carefully read the full contents of these papers and documented all the necessary information in a table. Due to space constraints, in Appendix 1, we present an in-depth review of 30 key representative primary papers only, covering some of the themes which we have identified in our review of the literature. We summarize research focus, sample sizes, variables and measurements, statistical techniques and findings of key 
mechanisms and firm characteristics that influence corporate tax planning). Second, we analyse the contents of these papers (Suddaby and Greenwood, 2005) which are expected to make a direct and explicit contribution to the literature of MNEs and corporation tax. Third, we evaluate the consistency and reliability as well as the contributions to the literature and summarize the results of our analysis in a framework (Figure 1).

\section{Figure 1}

\section{FINDINGS AND DISCUSSION}

\subsection{State of Research within IB Literature on MNEs and Corporate Tax Planning}

Because our paper adopts an IB perspective, we commence with a review of the existing relevant IB literature. We examine the contribution of IB papers and how they interact to provide a view of MNEs and their tax planning strategies. We then consider where there are gaps in the literature and introduce work from other fields with different perspectives that can usefully contribute to generating a better understanding of MNE tax planning. At the end of the paper, we note where research gaps remain and where additional research could usefully focus. The aim is to stimulate greater research in this area which we believe could be an important element in understanding the overall strategies and behaviours of the MNE.

\subsubsection{Internalisation theory and the treatment of corporation tax and other financial issues within the theory}

Internalisation theory (Buckley \& Casson, 1976; Rugman, 1981; Hennart, 1982) emphasizes the ability of the MNE to replace external markets for either proprietary knowledge or intermediate goods with managerial decision-making. Internalisation enables the MNE to overcome imperfections in external markets including both those that arise naturally and those that are imposed by governments. Tax is included in this approach as it is a government imposed imperfection. Firms will internalise their activities up to the point of efficiency, where the costs of doing so remain lower than the perceived benefits. 
The importance of transfer pricing in MNE tax planning has always been part of IB research. We argue, however, that after a strong interest up to the late 1980s research interest in tax from within IB appeared to wane. Lorraine Eden is clearly the exception with an impressive body of research that has spanned from the theoretical to the immensely practical (Rugman $\&$ Eden, 1985; Eden, 1998; Eden, 2003; Eden \& Kudrle, 2005; Eden, Valdez \& Li, 2005; Eden, 2016). The focus of early IB literature was on transfer pricing and the ability that transfer prices confer on MNEs to shift profits between different locations in particular. Transfer prices are an essential part of MNE activity, where they are used to value the flow of intermediate goods or services between affiliates of the same firm. Tax becomes an issue when transfers are made between affiliates in different tax jurisdictions. OECD guidelines state that these transfer prices should be accounted for as if they were "arm's length" transactions with an external third party (OECD, 2010). The arm's length price is the price that exists or would exist on the sale of a given product or service between unrelated firms. This relies on the existence of an external market to provide reference prices. If no such market exists, which may be the case particularly for transfers of intermediate or knowledge-based goods or services it is difficult to assess whether the prices used equate to 'arm's length' prices. Different entities may use resources jointly, particularly knowledge related assets which can exacerbate the pricing difficulties.

We find that transfer prices were at the core of internalisation theory as it developed (Buckley \& Casson, 1976; Rugman, 1980, 1981). Transfer pricing was not seen simply as a mechanism to enable an MNE to manage its internal affairs, but also as offering an important advantage to the MNE over the domestic firm. In 1979 Casson (1979) pointed out that the potential advantages gained from transfer prices may in themselves be enough to instigate the internalising of markets and the creation of the MNE. Analysis considered how firms managed and priced the transactions that they had internalised. The use of transfer prices offered potential for the MNE to make significant gains from internalisation as their use could improve 
the performance of an MNE (Horst, 1971; Nieckels, 1976; Lessard, 1979). Rugman (1980) concludes that transfer prices: "are an efficient response by the MNE to exogenous market imperfections" (Rugman 1980, p.76). Once an MNE is established, all transactions between the head office and subsidiaries must be accounted for and the transfer pricing used will affect the firm's overall profitability as well as the allocation of profits between subsidiaries. The use of transfer pricing is therefore synonymous with the establishment of an MNE.

The role of transfer pricing in driving the formation of the MNE also helps to explain why MNEs are concentrated in R\&D intensive and knowledge industries (Buckley \& Casson, 1976). These are areas where transfer pricing may be more opaque, reflecting the difficulty in assessing the true value of internal transfers from outside the firm. There are few comparable transactions that can be used to compare prices in order to enforce the arm's length price standard. This confers greater ability on the MNE to gain through manipulation. Early empirical work by Vaitsos (1974) and Lall (1979) confirmed the importance of transfer pricing to firms in knowledge intensive industries, such as the pharmaceutical industry.

Internalisation enables the MNE to overcome natural market imperfections (including transaction costs, improved information and knowledge sharing and greater levels of trust) and structural market imperfections (that the market for inputs and finished goods are not perfectly competitive). A key advantage for the MNE is the ability to benefit from differences in factor input prices in different locations, from differences in government regulations and from differences in statutory corporate income tax rates (Rugman \& Eden 1985). Profit shifting from high to low tax jurisdictions and the use of tax havens are examples of the ways in which MNEs use differences in tax rates between countries to generate higher economic rent.

Early theoretical work drew on work from economics and concluded that corporate income tax has an impact on the transfer pricing charged for intra-firm transactions (Copithorne, 1971; Horst, 1971; Samuelson, 1982). Economic models were created to attempt to derive the optimal 
tariff and transfer prices for firms operating in more than one country (Horst, 1971). An important book (Rugman \& Eden 1985) brought together the work by a number of key scholars (including but not limited to Aliber, Diewert, Eden, Itagaki, Samuelson, and Rugman) in order to set a research agenda and this underlines the importance with which transfer pricing was viewed at that time.

Synergies and the competitive advantages that the business gains from being an MNE are at the core of internalisation theory. As a direct consequence of internalising transactions the subunits of the business work together in a cooperative manner rather than the competitive way that they would operate in the external market. The gains from being an MNE undermine the rationale for the arm's length price standard. The arm's length price functions on the basis that internal transactions can be priced in the same way that they would be priced in an external market transaction. The gains from internalisation, however, mean that it may not be possible to "normalise" an MNE's profit by charging the same as they would to an external third party. The arm's length price standard ignores the fundamental gains that are made by virtue of being an MNE. There is no part of the arm's length price standard that accounts for how these gains should be treated. The theory underpinning the arm's length price standard therefore disregards the fundamental advantage that the MNE gains from internalization (Eden, 2016). Specifically, building upon internalization theory (Buckley \& Casson, 1976; Casson, 2015; Rugman, 1981), Eden (2016) argues that if the internalisation of knowledge transfers is one of the fundamental reasons for the creation of the MNE then the advantage that the firm gains from this internalisation cannot easily be measured or reflected in transfer pricing (Eden, 2016). There is therefore a flaw in the theoretical assumption behind transfer pricing of normalising the MNE's profit. Consequently, the arm's length price standard has been criticised conceptually, politically and legally (Rugman, 1980; Shoen, 2011; Eden, 2016). 
The literature on MNEs' transfer pricing compares prices for intra-firm/ related party versus external third party/ unrelated party trade within specific industries or product groups. Even more recently, empirical work focusing on transfer pricing remains scarce despite its importance to managers within international businesses. Data on transfer pricing remains exceedingly difficult to access as firms do not have to make this information public. Researchers who have worked in this area have had to develop innovative research methodologies. For example, Eden, Valdez \& Li (2005) consider the severe penalties for transfer price manipulation that were introduced in the US in 1990 and their reflection in the reduction in market value (down 12.6 per cent) of Japanese MNEs with US subsidiaries as a direct consequence of the introduction of penalties. They conclude that this is evidence of the significant value derived from transfer price manipulation.

The importance of finance to the MNE was acknowledged by the early proponents of internalisation theory who placed emphasis on the potential advantages to the MNE over domestic firms from aspects of finance, especially the role of MNE internal capital markets (Rugman, 1980, 1981). Specifically, Rugman (1980, 1981) builds financial markets into his explanation for the existence of the MNE, explicitly including imperfections in financial markets as drivers for internalisation, which in turn lead to the creation of internal capital markets.

Lessard (1979) also considers the potential gains from finance for the MNE. He examines imperfections in the international financial markets; the degree of segmentation or integration between national capital markets. He shows that when external markets for intermediate products, or financial aspects are imperfect, the MNE has an incentive to bypass them and create internal markets. Rugman (1980) cites Lessard and concludes that financial market imperfections, including international tax rate differentials, provide an impetus for the firm to avoid these by creating an internal capital market. 
There is little empirical IB literature on the financing of MNEs, especially on how to finance foreign subsidiaries. Mudambi (1999) and Aulakh \& Mudambi (2005) are two important studies. Mudambi (1999) examines the working of internal capital markets taking into account the granting of strategic independence of subsidiaries in relation to the headquarters and their control of resources. Aulakh \& Mudambi (2005) examine the financial flows within MNEs and find that external capital market conditions affect the use of internal capital markets. More recent research combining internalization theory in the IB literature and the pecking order theory in the finance literature has emphasised the importance of understanding the role that access to capital, particularly internal financing sources can play in driving corporate strategy (Nguyen, 2013; Nguyen \& Rugman, 2015; Nguyen \& Almodovar, 2018).

We find that as internalisation theory developed, the emphasis changed, with writers focusing more on the role of intermediate product transfers and more particularly, on knowledge flows as key advantages for the MNE. Work moved away from the advantages from internalisation derived from financial market imperfections, synergies and transfer pricing. This move away from transfer pricing as a driver for internalisation, may have been due at least in part to the difficulty of obtaining data in order to empirically test the theories that were developed, although some early empirical work does exist (Vaitsos, 1974; Lall, 1979).

It is likely that concern in the 1970s about the power of MNEs and their ability to erode the sovereignty of governments created an interest in transfer pricing and corporation tax avoidance. During the 1980s these concerns appeared to lessen. The 1980s and 1990s brought a change in attitude with a period of "redemption for the multinational enterprise" (Vernon, 1998 p.5). This attitude towards the MNE appears to be reflected in a decline in the number of articles published in relation to tax avoidance in IB journals.

\subsubsection{Dunning's eclectic paradigm, the location choice and the motivation to avoid tax}


Dunning's eclectic paradigm or OLI framework (ownership-specific advantages, locationspecific advantages and internalisation advantages) and four broad FDI motives (marketseeking, efficiency-seeking, natural resource-seeking and strategic asset seeking) are among the key theoretical foundations in the field of IB (Dunning, 1993). These theories are directly relevant to the study of corporation tax. Location choice and the potential for competitive advantage to be derived from this, have been a key focus of IB research and play an important role in profit shifting activity. The broad FDI motives may enhance our understanding of the motivations of tax avoidance.

With regards to ownership-specific advantages, there may be sufficient efficiencies to be gained, through the use of transfer pricing, the avoidance of higher tax rates or tariffs or other financial synergies to generate sufficient efficiency for the establishment of an MNE. Efficient tax planning operationalized through profit shifting can give the MNE a significant advantage over the purely domestic company. Some of the efficiencies may be incorporated into what Dunning referred to as a "financial asset advantage" (Dunning, 1993 p.150). Dunning does not specify exactly what this would include but points out that a financial asset advantage is usually a result of the size, efficiency and knowledge of the MNE. Oxelheim, Randoy and Stonehill (2001) consider what could be included within this "financial asset advantage" and group MNE strategies into 1) proactive strategies that are under the control of the MNE and 2) reactive strategies adopted in response to financial market failure. The MNE is, however, established in response to market failure, thus if there were no market failure there would be no MNE and no way of gaining a "financial asset advantage". This dichotomy collapses (Jones \& Temouri, 2015) but it is not an essential part of Oxelheim et al's (2001) argument. Oxelheim et al (2001) discuss a series of pertinent hypotheses, each of which could give a skilled MNE an advantage over their competitors, both nationally and internationally. They include, within their list of hypotheses, the hypothesis that a firm is: "more likely to engage in FDI when it is 
able to negotiate reduced taxation and / or subsidies for financing it" (Oxelheim et al 2001, p. 392). These hypotheses have remained at conceptual level and they have not yet been empirically tested.

Location-specific advantages (LAs) are the advantages offered by countries, making them attractive to the MNE as a place to do business. Different countries have different sets of resources and prices that make operating a business there either more or less attractive. Empirical work from outside the IB field has now widely accepted that tax differentials between countries affect the behaviour of MNEs, providing empirical evidence for the importance of tax as a determinant of LA (Markle \& Shackelford, 2009; Hanlon \& Heitzman, 2010; Dharmapala \& Riedel, 2013; Fuest, Spengel, Finke, Heckemeyer \& Nusser, 2013; Taylor, Richardson \& Lanis, 2015). Any MNE choosing to locate in a particular country will be able to take advantage of the LAs it offers. The growth in tax competition between countries increases the ability of MNEs to benefit from differences in locations, from differences in government regulations and from differences in statutory corporate income tax rates (Rugman \& Eden, 1985).

IB literature on broader FDI motivations can also contribute to our understanding of what drives MNEs to avoid tax through profit shifting. Understanding what drives FDI, where and how investments are made, is key to understanding the behaviour of the MNE (Dunning, 1993; Rugman, 1981; for a review, see Rugman, Verbeke \& Nguyen, 2011). Dunning's classic (1993) work developed FDI motives and as we note above, focus since then has been on the four main motives he outlined: market seeking, efficiency seeking, natural resource seeking and (strategic) asset seeking. Dunning (1993), however also includes other motives for FDI that have been neglected in later work. These include: escape investments, support investments and passive investments. Dunning explicitly includes corporate tax avoidance as a motivating factor within "escape investments". These investments include those specifically made by an 
MNE to facilitate avoidance (escape) of high levels of corporate taxation in the home country. More recent work (van Tulder, 2015; Cuervo-Cazurra, Narula \& Un, 2015; Cuervo-Cazurra \& Narula, 2015) has pointed out the unwarranted neglect of these wider motivations. Witt \& Lewin (2007) also emphasise the "escape" role of FDI as a response to institutional constraints or regulations, including high taxes in the home country. The host country must therefore offer corresponding locational advantages.

Others have argued that theory that incorporates an explanation of behavioural aspects of decision making will enhance the understanding of the way decisions are made. This school of thought is based on the work of Simon (1957) where the firm is studied in terms of observed behaviour rather than as an objective function specified ex-ante. The behavioural theory contends that the firm operates according to rules of thumbs, established through interpersonal conflict and compromise within the firm, and in response to a specific environment. Behavioural theorists interpret the firm's decision-making process as aimed at tangible goals, understood by corporate personnel at various functional levels (for a summary, see Kopits, 1976).

IB theory incorporates the assumptions of rationally bounded behaviour by managers and the information asymmetries that they face. This does not, however, offer a complete understanding of the behaviour of managers. Managers make decisions that satisfice rather than optimise. Cuervo-Cazurra et al (2015) offer a model of the motives of internationalisation based on behavioural economics. They conclude that the motives for internationalisation can be split into: "an economics driven exploitation of existing resources, or exploration of new resources and a psychology driven search for better host country conditions or avoidance of poor home country conditions" (Cuervo-Cazurra et al 2015, p.2). These IB theoretical propositions remain at a conceptual level but we posit that they could be valuable in generating a greater understanding of the decisions made within MNEs about their tax planning approach. 
Indeed, a recent qualitative study based on a series of interviews with senior tax executives of US MNEs with operations in the UK and tax advisory firms has gained useful managerial insights and concludes that managers may 'optimise' rather than 'minimise' their effective tax rates (ETRs) (Cooper \& Nguyen, 2019). IB research which incorporates the behaviour of managers could usefully contribute to an understanding of the 'optimal' ETR and therefore corporate strategy.

It seems likely that the difficulty of accessing empirical data, combined with a more positive outlook on the role of MNEs reduced the impetus of IB scholars to perform empirical work in this area. Recent articles have acknowledged the importance of tax to IB scholars and the importance of this area in understanding the broader strategies of MNEs (Contractor 2016a;b; Foss et al., 201).

There are a small number of recent IB studies that have contributed to an understanding of the role of tax havens. Research by Jones and Temouri (2016) and Jones, Temouri \& Cobham (2018) has focused on the important role of tax havens in facilitating tax avoidance and their value to MNEs. This work is firmly based in IB theory, using Rugman's country-specific advantages and firm-specific advantages (CSAs/ FSAs) to generate an understanding of the ways in which tax avoidance contributes to MNE strategy (Jones et al., 2018; Jones \& Temouri, 2016). Tax havens are characterised by having very low or zero rates of corporation tax and high levels of secrecy that make them attractive to MNEs (Shaxson, 2011; Zucman, 2015). This secrecy compounds the difficulties inherent in tax research. Even classifying countries as tax havens is difficult. Jones \& Temouri (2016) contribute to the debate on the definition of a tax haven, analysing the essence of a tax haven for companies that are "non-resident".

Jones \& Temouri (2016) conclude that the home country's statutory corporation tax rate has little impact on the decision to invest in a tax haven as there are likely to be significant savings 
from using a tax haven, whatever the home rate. We suggest that the US statutory rate's recent reduction from 35 per cent to 21 per cent in December 2017 may offer researchers the ability to observe the impact that this has on corporate behaviour and strategy in the future.

On the basis of our analysis of the literature, we suggest that more, broader research is needed from an IB perspective on the role of tax strategy and tax avoidance which is important to enhance an overall understanding of the MNE. We consider some of the broader areas of tax that are clearly important to IB research but that have until now, been more empirically addressed by researchers from within other fields. This section aims to summarise the extant research that could be useful to those working within IB, whilst also explaining the IB research that exists within the context. The next sections pull together a comprehensive literature review and assessment on areas where future research could generate significant new insights for IB.

\subsection{State of Research within Other Fields on MNEs and Corporate Tax Planning}

\subsubsection{Challenges of Conducting Empirical Research}

The confidential nature of tax planning creates one of the key challenges for researchers across disciplines - gaining access to relevant and timely data. Corporate tax returns are confidential submissions to the tax authorities and can only infrequently be accessed by researchers (Grubert \& Mutti, 2000), leaving the audited annual financial accounts as the main source of evidence for researchers. These access problems may have reduced the incentive or ability to conduct research in this area, particularly for those from the field of IB, because this research requires a combination of detailed knowledge and skills in economics, finance, law and accounting and knowledge in international business. Hanlon \& Heitzman (2010) call for accounting researchers to use their understanding of corporate accounts: "to examine 'real' corporate decisions". In the same spirit, we call for IB researchers to use corporate accounts 
to gain greater understanding of the real actions and their implications for "real" corporate strategy.

Identifying profit-shifting behaviour empirically is inherently difficult. MNEs are not currently required to disclose their sales or profits on a country-by-country basis (the new $\mathrm{CbC}$ reporting requirements will, when and where implemented, require MNEs to disclose this to local tax authorities but the information is unlikely to be available to researchers). Most studies therefore consider indirect measures of tax payments and where profits have been made. Researchers face further complications surrounding the use of tax havens and/or OFCs. Practically however, there is no single accepted definition to determine which countries are classified as tax havens. The level of secrecy around such operations also makes accessing data on affiliates in these locations extremely difficult.

Until recently, the rate of corporation tax in the US was significantly higher (a federal rate of 35 per cent) than the OECD average (25.5 per cent, Tax Foundation, 2013) providing US MNEs with significant arbitrage opportunities, encouraging them to consider carefully where their profits were booked and consequently taxes were paid. President Trump has introduced far ranging changes to the corporate tax system in December 2017. Whilst a full discussion of these changes is outside the scope of this paper, we note that the reduction of the statutory corporation tax rate to 21 per cent at the end of 2017 and changes to the way that overseas earnings are taxed has the potential to have considerable impact on the way that MNEs plan their tax affairs. We argue that the lack of theoretical underpinning for research in this area again, creates difficulties in anticipating the impact that the reforms are likely to have on US MNEs.

On the other hand, previous studies also report that emerging market firms are becoming more aggressive in tax avoidance. Investments made by firms from Hong Kong, China, Brazil, India and the Russian Federation into tax havens and OFCs have increased (UNCTAD, 2016). These 
internationalization activities are mainly for "round tripping", referring to "going out" to invest in third countries and then investments are made back into the countries of origin ( $\mathrm{Lu}, \mathrm{Liu}$, Wright \& Filatotchev, 2014; Meyer, Ding, Li, \& Zhang, H. 2014; Morck, Yeung \& Zhao 2008). Such flows are more akin to domestic investments disguised as outward FDI (UNCTAD, 2013) but further work is needed to understand their impact on local economies as well as their distorting effect on international statistics.

\subsubsection{Estimating the scale of profit shifting and tax competition between countries}

A significant body of research, particularly from the perspectives of public economics and accounting has clearly shown that tax differentials between countries affect the behaviour of MNEs. Competition between countries has intensified as they fight to attract FDI by lowering tax rates (Altshuler and Grubert 2002; Azemar 2010; Dharmapala and Riedel 2013; Fuest et al 2013; Markle and Shackelford 2009; Hanlon and Heitzman 2010; Rego 2003; Taylor, Richardson and Lanis 2015). Whilst it is difficult to fully assess the extent of profit shifting, research at this aggregate level has demonstrated that firms have considerable ability to shift their profits (Grubert and Mutti 1991; Hines and Rice 1994; Huizinga and Laeven 2008), that this ability is increasing (Altshuler, Grubert and Newlon 2000; Klassen and LaPlante 2012; Zucman 2014) and that MNE are becoming more sensitive to tax rates (Altshuler, Grubert and Newlon 2000).

Tax differentials, combined with the home and host tax regulations (Dyreng et al 2015) have an impact on the location and amount of capital invested abroad (Barrios et al 2012; Dischinger and Riedel 2011; Grubert and Mutti 2000; Voget 2011); the way in which the investment is financed (Egger et al 2010; Gordon and Lee 2001; Harrington and Smith 2012; Taylor and Richardson 2013); transactions between related parties within the MNE corporate network (Brajcich et al 2016), and the repatriation of earned profits (Altshuler \& Grubert 2002; Blouin, 
Krull \& Robinson 2012; Brajcich, Friesner and McPherson 2013a). These are all clearly major areas of strategic concern to the MNE.

One considerable stream of research attempts to evaluate the scale of tax avoidance by MNEs with different methodologies leading to different estimations. For example, the OECD has estimated that between 4 and 10 per cent of global tax revenues are lost (OECD, 2017). Other organisations including the EU, the UK and US governments and the IMF (IMF, 2018) also have active work programmes in this area. The global financial crisis of 2008 and the consequent impact on government fiscal revenues stimulated affected bodies to investigate tax receipts from corporations in an attempt to boost government revenues.

The scale of profit or income shifting to avoid taxes appears to be growing. Between 2003 and 2008 , income booked through holding companies accounted for an average of 4 per cent of income for US FDI. By 2015, this had increased to an average of 52 per cent (UNCTAD, 2016). A foreign holding company is defined as an immediate parent undertaking of a subsidiary or a portfolio of subsidiaries, dealing specifically with assets, investments and management, rather than providing goods and services with a view to making a profit from production and sales. Assets could be in the forms of shares, intellectual property (patents, trademarks) and real property (real estates) and other assets, etc.

One of the common approaches in the literature is to compare pre-tax profits of high-tax and low-tax affiliates as profit shifting reduces the former and increases the latter (Riedel, 2018). The size of the estimates, however, varies across studies. Sullivan (2004) and Clausing (2016) find strongly elevated pre-tax profitability rates at tax haven affiliates in the case of US MNEs using data provided by the US Bureau of Economic Analysis (BEA). Riedel (2018) argues that besides tax reasons, the differences in profitability may reflect variation in other profitability determinants across host countries and affiliates, such as differences in worker productivity, 
public good provision or market competition. Heckemeyer and Overesch (2017) perform a meta-analysis and find a semi-elasticity of 0.8 as a consensus estimate.

According to Riedel (2018), the literature also proposes two alternative approaches to test MNE profit shifting. The first approach, proposed by Dharmapala \& Riedel (2013), examines profitability shocks to MNE affiliates as a source for empirical identification. The second approach to quantify tax losses through profit shifting was proposed by Egger, Eggert \& Winner (2010) and Finke (2013), and focuses on comparing the corporate tax payments of MNEs and domestic firms.

Dharmapala (2014) conducts a survey of empirical literature and finds that in the more recent literature, which uses new and richer sources of data, the estimated magnitude of profit shifting is typically much smaller than that found in earlier studies. Dyreng, Hanlon, Maydew \& Thornock (2017) examine systematic changes in corporate effective tax rate (ETR), defined as a measure of tax charged as the numerator with a measure of income as the denominator, over the past 25 years. They find that ETRs have decreased significantly. Contrary to conventional wisdom, the decline in ETRs is not concentrated in MNEs; ETRs have declined at approximately the same rate for both MNEs and domestic firms. Moreover, within MNEs, both foreign and domestic ETRs have decreased. Finally, changes in firm characteristics and declining foreign statutory tax rates explain little of the overall decrease in ETRs.

Taking a macro-economic perspective, Zucman (2014) computes the ETR on profits recorded by US MNEs on a world-wide basis, and finds that the overall ETR fell from approximately 30 per cent in 1998 to 20 per cent in 2013 , whilst the statutory rate was unchanged at 35 per cent. Zucman (2014) also finds a key role for tax havens. He reports that 20 per cent of all US corporate profits are now booked in tax havens. He calculates that about two thirds of the 10 per cent decline in US MNE's ETR can be attributed to increased profit-shifting to low-tax 
jurisdictions. Zucman (2014) also finds that the use of tax havens has grown ten-fold since the 1980s.

Our review reveals that MNEs have the ability to shift profits, moving profits to countries with lower rates of corporate tax. This finding holds for both US firms (Klassen \& LaPlante, 2012; Azemar, 2010), European firms (Dharmapala \& Riedel, 2013) and those based in the OECD (Bartelsman \& Beetsma, 2003). The lack of data makes evaluating the extent of the profit shifting difficult but Dharmapala \& Riedel (2013) find that the magnitude is small (at 2 per cent) but statistically significant. Azemar (2010) concludes that a 1 per cent increase in the tax rate is associated with 2.5 per cent greater dividend payments as a higher tax rate reduces the differential between the US and host countries. By comparing two five-year periods, Klassen \& LaPlante (2012) conclude that the extent of profit shifting is growing. Bartelsman and Beetsma (2003) find that government revenues are negatively affected.

A number of studies have considered the impact of MNEs profit shifting directly on developing countries and have attempted to evaluate the losses to these countries (Cobham 2005). Fuest \& Riedel (2009) present a review of the relevant research and conclude that developing countries are missing out on between $\$ 35$ billion and $\$ 160$ billion per year. That their estimate is so broad reflects the methodological difficulties encountered, difficulties also encountered by governments attempting to evaluate the efficacy of their inward FDI policies.

Some of the methodological issues encountered by researchers are related to the availability of data. Many of the quantitative studies that we have considered for this review use data from Orbis and Amadeus (both databases are provided by Bureau van Dijk databases) or Bureau of Economic Analysis (BEA) data in the US. These databases (and others) are limited as the data is sourced from publicly available annual reports. Many countries that are important in tax avoidance (including, but not limited to tax havens) do not require companies to publish 
financial information and the scope of available data is therefore limited (Huizinga \& Laeven, 2008; Finer \& Ylonen 2017; Dharmapala, 2014). The BEA data focuses only on US firms (Clausing, 2016; Desai, Foley \& Hines, 2004) and the data collected by the Central Bank of Germany focuses only on FDI by German firms (Buettner \& Wamser, 2013). These data sets are therefore limited in their ability to generate general information about global tax avoidance as well and studies using them may not be generalizable for the whole population of MNEs from different countries and regions around the world. Clausing (2016) notes the weaknesses with much of the available data and points out the importance of including data from tax havens as her work reveals that just seven tax haven countries are used by firms engaging in 82 per cent of US profit shifting.

There are other limitations: these databases do not provide data on a company's tax residence - implicitly assuming that the country of incorporation is synonymous with its tax residency (Finer \& Ylonen, 2017). Companies such as Google, for example, have subsidiaries which are incorporated in Ireland but are resident in Bermuda for tax purposes (there is no corporate income tax in Bermuda and a company is considered a tax resident of Bermuda if it is incorporated in the country). Thus, research which generates a comprehensive view of tax avoidance must be based on a real understanding of the complex structures employed by MNEs.

A further issue with much quantitative research is the focus on comparison of statutory corporate tax rates. These are the published headline rates and therefore provide a simple point of comparison between countries. They may, however, be misleading as authorities in different countries provide different tax incentives to attract FDI by lowering the incidence of corporate tax. Revelations about the deals between digital companies such as Apple and the authorities in Ireland reveal the limitations of comparing statutory rates (Brinded, 2016). Differences 
between the enforcement of tax regulations also differ between countries and a good understanding of this may also be exploited by MNEs (Muller \& Kolk, 2015; Durst, 2016).

Torlsov, Wier and Zucman (2018) discuss the limitations of quantitative research using information from databases; instead, they rely on data published directly by the statistical institutes of most of the world's developed countries, including the major tax havens. This macroeconomic data, known as foreign affiliate statistics, is a source of data published relatively recently by countries such as Luxembourg, Ireland and the Netherlands and now provides a much broader and complex data set than is available through the use of databases such as Orbis. These data sets make it possible to break down the national account aggregates of the main tax haven and non-tax haven countries by firm ownership - foreign-owned firms versus local firms which can then be used to quantify the international mobility of profits (Torlsov et al., 2018).

On the other hand, a large body of works, including those by the OECD examine profit shifting using corporate financial and balance sheet data, collected by the Orbis database of Bureau van Dijk. One limitation of this dataset is that little micro-level data exists about the profits booked by MNEs in low-tax countries. Orbis provides information about the global consolidated profits of most of the world's MNEs (Cobham \& Loretz, 2014). MNEs, however, are generally not required to publish their profits country by country or subsidiary by subsidiary. Orbis relies on administrative information available in public business registries (collected by Chambers of Commerce throughout the world) to record how much profit MNEs make in their various subsidiaries. Because countries such as France maintain comprehensive registries, almost all the profits made by French resident firms (including subsidiaries of foreign MNEs) can be seen in Orbis. In many other countries, however, public registries are much more limited: they either do not exist (e.g. Bermuda), or they exist but provide no income information (e.g. the United 
States, Ireland, Switzerland, etc.). As a result, much of the profits booked by MNEs in these countries are not visible in Orbis (for a comprehensive discussion, see Torslov et al., 2018).

We suggest that researchers in this field must be aware of the limitations of the data that is available and whether it is comprehensive and relevant for their needs. The recent requirement for Country by Country $(\mathrm{CbC})$ Reporting from the OECD will generate new data for governments (80 countries have adopted this measure to date) but unless mandatory publication is implemented the usefulness for research will be limited.

\subsection{Mechanisms of Profit Shifting Used in MNE Tax Planning}

Whilst the work discussed above provides evidence of profit shifting it does not address the specific mechanisms by which MNEs are able to move profits. Different MNEs will be able to take advantage of different profit shifting mechanisms more easily than others. MNEs may choose to focus on one mechanism or engage with several mechanisms in a broad tax planning strategy. Little is known, however, about the choices made in terms of mechanisms that MNEs decide to use in planning their tax affairs.

We review studies from other fields that have examined the specific mechanisms used by MNEs to shift profits. We start by considering these studies which complement the IB works discussed in the sections 3.1.1 and 3.1.2. The next sections focus on different mechanisms that are available to MNEs to pursue a profit shifting agenda. Previous studies tend to concentrate on specific mechanisms, their use and implementation, but do not generate a holistic view of how tax planning fits into the overall corporate strategy of the companies involved. We summarise what is known about the different mechanisms but posit that work from an IB perspective could make a significant contribution by specifically considering the implications of tax planning for broader corporate strategy. The lack of theory makes prediction about the formulation, implementation and evaluation of tax planning strategies difficult. Work is needed 
from an IB perspective that generates an understanding of which companies are likely to engage in which tax planning techniques and why some appear to pursue these policies more aggressively than others. The lack of research means that it is difficult to assess the importance of different methods in comparison to each other (Fuest et al 2013).

\subsubsection{Transfer Pricing}

IB scholars have recognised the importance of transfer prices, particularly their role in the theoretical underpinning of internalisation theory (Buckley \& Casson, 1976; Rugman, 1980, 1981). As noted in Section 3.1.1, transfer prices play a key role in the management of any MNE and it is important that this gap is addressed. Little work from an IB perspective, has, however, pursued the empirical perspective after the very early work by Vaitsos (1974) and Lall (1973). The studies by Lall (1973) and Vaitsos (1974) contain direct statistical evidence on transfer prices. They document the overpricing of foreign owned subsidiary imports prevalent in Columbia in the pharmaceutical, rubber, and electronics industries. Lall (1973) found a particularly high incidence of overpricing by pharmaceutical subsidiaries, with a weighted average of overpricing ranging from 33 per cent to more than 300 per cent of international market prices, during the years 1966-70. Similarly, Vaitsos (1974) reported overpricing by pharmaceutical products averaging 155 per cent in 1968 . The overriding determinant of these practices was probably the quantitative ceiling on profit repatriation. But as several Columbian subsidiaries made their purchases through subsidiaries located in a taxhaven jurisdiction (Panama), and as the Columbian rate of protection on pharmaceutical imports was almost nil (see Vaitsos, 1974, page 48 and 91), the fiscal incentive may have been operational, too.

From an economics perspective, Clausing (2003) finds a key role for transfer prices. She determines that the prices used for related party transaction trade prices are influenced by MNE tax-minimization strategies. A tax rate that is just 1 per cent lower in the country of destination 
/ origin is associated with related party export prices that are 1.8 per cent lower and intra-firm import prices that are 2.0 per cent higher, relative to non intra-firm goods. Bernard, Jensen \& Schott (2006) report similar finding as in Clausing (2003). Cristea \& Nguyen (2016) examine transfer pricing of trade of Danish firms before and after they set up their foreign subsidiary. They argue that MNEs set the export price for external third-party trade to a value closer to the transfer prices of intra-firm trade in order to comply with the arm's length price standard of taxation.

\subsubsection{Capital Structure and the Use of Internal Debt}

Our review finds that finance, and in particular the capital structure of the firm and the use of internal debt, has the potential to play an important role, conferring the ability on the MNE to shift profits. The tax deductibility of interest expense makes debt financing relatively attractive to the MNE over funding by equity. Research shows that intra-firm lending, also known as internal debt and/or intra-firm loans is used to shift profits from high to low tax countries. An affiliate based in a high tax country borrows money from and pays interest to, an affiliate in a lower tax country. This reduces the profits in the interest paying affiliate and increases them in the lending affiliate or the group finance company when it receives the interest. ${ }^{1}$

We find that whilst prior research has identified unusually high levels of debt in high tax countries (Egger et al, 2010; Gordon \& Lee, 2001), it is difficult to conclude whether this is as a result of profit shifting or whether firms have more motivation to finance through debt because of the straightforward tax deductibility of interest. The levels and location of intrafirm debt is of interest when attempting to identify profit shifting behaviour. The firm's

\footnotetext{
1 OECD Transfer Price Guidelines (OECD 2010) state that interest payments should be transparent and set at an arm's length rate. The level of risk attached to the loan, however, is not always transparent and would legitimately influence the interest rate used (Overesch \& Schreiber, 2009).
} 
external debt may remain unchanged, making the identification of profit-shifting induced debt problematic.

Prior research confirms that the capital structure of subsidiaries is sensitive to the tax rate of the host countries in which they are based, with the spread of tax rates across subsidiaries affecting the level of debt (Altshuler \& Grubert, 2002; Buettner \& Wamser, 2013; Desai, Foley \& Hines, 2004; Dharmapala \& Riedel, 2013; Egger et al, 2010; Huizinga \& Laeven, 2008; Harrington \& Smith, 2012). The debt - asset ratios for MNE subsidiaries in high tax countries are higher than for those in low tax countries, and also for domestic firms (Egger et al ,2010; Gordon \& Lee, 2001). We find, however, that these studies focus on the total debt - asset ratio however, and do not distinguish between external and internal debt, due to the lack of data available specifically on internal debt.

When loans are used for profit shifting the external debt of the firm does not need to change. Affiliates lend and borrow from each other with the loans being financed from retained earnings or parental equity. The tax incentive to use more debt may therefore distort only the capital structure of the subsidiary. Altshuler \& Grubert (2002) and Desai et al (2006) show that US MNEs use debt financing to shift profits. Other work confirms this using European companies (Buettner and Wamser, 2007; Egger et al, 2010; Huizinga, Laeven \& Nicodeme, 2008).

Very few existing studies distinguish between internal and external debt as the data is difficult to access (only data published by the US Bureau of Economic Analysis and the Central Bank of Germany incorporate this distinction). Some IB researchers integrate accounting and finance in their research design by applying accounting standards in their questionnaire design to collect data on external and internal debt using surveys (Nguyen \& Rugman, 2015; Nguyen \& Almodovar, 2018). These studies conclude that there is a significant role for internal lending 
to fund exports (Nguyen \& Almodovar, 2018). It is not possible therefore to assume that all internal lending is related to purely tax planning purposes.

Graham (2003) surveys the empirical research work on taxes and capital structure and concludes that capital structure decisions appear to respond to corporate taxes. Graham (2003) notes however, that some academics (Myers, McConnell, Peterson, Soter \& Stern, 1998) suggest that, "Tax incentives are of a 'third order' of importance in the hierarchy of corporate decisions". There may be reasons other than tax for high levels of intra-firm borrowing. Desai et al. (2004) argue that MNEs have an advantage over purely domestic firms as they can substitute internal for external debt. The MNE can borrow externally in a favourable market and then lend internally to affiliates. The MNE can support affiliates in particular markets that have trouble accessing external debt because there is limited external credit opportunities or the cost of borrowing is high (Nguyen, 2013; Nguyen \& Rugman, 2015).

Whilst research agrees that MNEs use debt for profit shifting, the size of the effect established varies (Altshuler \& Grubert, 2002; Buettner \& Wamser, 2013; Desai et al, 2004; Dischinger \& Riedel, 2011). Whilst Buettner \& Wamser (2013) find only small, although statistically significant effects of tax on internal debt (using a dataset of German firms). Desai et al (2004) find that 10 per cent higher tax rates are associated with 2.8 per cent higher debt / asset ratios with internal debt being particularly affected (using a dataset of US firms). Altshuler \& Grubert (2002) demonstrate that the debt levels held by subsidiary companies are highly sensitive to the local tax rate. Egger et al (2010), use a large sample of European firms and find that MNEs have a substantially higher debt ratio than domestic firms with the difference between MNEs and domestic firms being related to the rate of corporation tax payable.

Our review shows the importance of internal debt as a profit shifting mechanism. As internal debt holdings tend to be small and the transferred income is the product of internal debt and the interest rate, the estimates, overall, imply relatively small debt-shifting volumes (see 
Buettner \& Wamser, 2013; Dharmapala 2014). A recent meta-analysis by Heckemeyer \& Overesch (2017) confirms this notion (see the review by Riedel, 2018).

In a related manner, recent research examines the impact of thin capitalization ${ }^{2}$ rules introduced by governments which aim to limit MNEs' ability to engage in tax planning via debt (Mardan, 2017; Buettner, Overesch \& Wamser 2018). Buettner et al. (2018) test how limitations of interest tax deductibility under thin capitalization tax rules and how the regulations of transfer pricing by host countries, affect investment and employment in foreign subsidiaries. They find that introducing a typical thin capitalization rule exerts a significant adverse effect on FDI and employment where taxes are high. Moreover, in countries that impose thin capitalization rules, the tax rate sensitivity for FDI increases. Regulations of transfer pricing, however, are not found to exert significant effects on FDI or employment.

\subsubsection{Location choice}

\section{The location for real economic activity}

When MNEs are expanding abroad, decisions on location are likely to be impacted by both home and host country taxes (Barrios et al, 2012; Huizinga \& Laeven, 2008). Our review of prior empirical research from other fields confirms a negative relationship between the statutory tax rate in place and FDI (Azemar, 2010; Barrios et al, 2012; Devereux \& Griffith, 2003; De Mooij \& Ederveen, 2006). The corporation tax rate is, however, only one aspect that will affect a company's decision on where to locate. The comparative rates of corporate tax will be built into the overall analysis of the Location-Specific Advantages including other traditional factors, such as the size of the market or the cost of labour, etc. The interaction of the home and host country tax systems will be considered as MNEs seek to implement a

\footnotetext{
2 A company is said to be thinly capitalised when the level of debt is much higher than the equity capital, that is, its gearing is very high.
} 
strategy that ensures that their overall pattern of international ownership is tax efficient and takes both the statutory and effective rates of tax in both home and host countries into account (Barrios et al, 2012; Buettner \& Ruf, 2007; Clausing, 2009; Devereux \& Griffith 1998).

A significant number of empirical studies considering tax-related location decisions come from other fields. Barrios et al (2012) consider the ability of European MNEs to shift the location of their economic activity. They find that subsidiaries with lower levels of fixed assets respond more to home and host country taxation as higher levels of fixed assets make moving subsidiaries more difficult. They also find that the location decisions for highly profitable subsidiaries are less responsive to tax inducements than are less profitable subsidiaries. They speculate that higher profitability could be location specific, so moving the subsidiary could reduce profitability. Location decisions of foreign subsidiaries with low fixed assets are more sensitive to parent and host country taxation - reflecting the fact that they are physically easier to move than subsidiaries with higher levels of fixed assets. Tax interacts here with profitability and fixed assets to guide location choice in a way that indicates that a fuller understanding of how these decisions are made is needed.

A stream of work from within the accounting field looks at the supply chains of US MNEs (Dyreng et al, 2015) and considers how tax and non-tax country characteristics affect location decisions and the use of foreign holding companies. This work shows that US MNEs with more profit shifting capacity are less likely to use foreign equity holding companies. These MNEs have less need to generate structures to repatriate dividends in a tax efficient manner as they have the capacity to shift profits within their existing structures. Clearly, dividend repatriation is a decision influenced by the tax implications of when and how funds are transferred to the home country. 
Inversions are when a parent company buys a foreign subsidiary and then inverts the ownership structure such that the new subsidiary becomes the parent company. The use of inversion demonstrates the importance of location and the role of tax in determining location choice. The extant academic research, largely focused on US companies and largely published in economics and finance journals finds a significant role for inversion in corporate strategy (Desai \& Hines, 2002; Seida \& Wempe, 2004).

Inversions have been politically controversial in the US in recent years as they allow MNEs to completely bypass the domestic tax system (Boise and Koenig, 2002). Recent proposals in the US will make it harder for companies to invert (Financial Times, 2016) and the recent drop in the statutory tax rate may also reduce the attractiveness of such activity. There is little recent research that takes a rigorous approach to evaluating the attractiveness of inversion to companies from the US or elsewhere. Anecdotal evidence such as the failed \$160billion Pfizer / Allergan merger (Financial Times 2016) demonstrates the importance of tax as a driver of corporate strategy. The proposed merger failed when changes to US regulations meant that Pfizer would not be able to invert and base its headquarters in Ireland following the takeover. Without the promise of low Irish tax rates the merger was not sufficiently attractive to go ahead (Financial Times, 2016).

\section{The Use of Tax Havens}

As noted in Section 3.1.2., research from an IB perspective has recently focused on the role that tax havens play in tax planning strategies. The importance of tax havens is indicated by the size of the body of research that examines them from a number of perspectives. Much of this work is from a finance or economics perspective. Research splits tax havens into "dot tax havens", essentially small island economies and the 'Big Seven' (Hong Kong, Ireland, Lebanon, Liberia, Panama, Singapore and Switzerland) economies that have low or zero 
taxation but also have significant markets that may also be attractive to MNEs (Hines \& Rice, 1994).

Research has attempted to evaluate the extent of tax haven use by MNEs (Desai, Foley \& Hines, 2006) although other researchers have noted that the number of tax haven subsidiaries is less important than how the group is structured (Dyreng \& Lindsey, 2009). Other research has demonstrated the link between US investments in tax havens and profit shifting (Hines \& Rice, 1994; Grubert \& Slemrod, 1998; Taylor, Richardson \& Lanis 2015; Jones \& Temouri, 2016).

Research from a financial perspective underlines the scale of tax haven use and the importance of this topic for those wanting to understand trade and FDI flows. Recent research (Zucman, 2014; Zucman 2015) uses US balance of payments data and determines that 55 per cent of US foreign profits are made from six countries that are classified as tax havens: the Netherlands, Bermuda, Luxembourg, Ireland, Singapore and Switzerland. Zucman (2014) reports that foreign profits have increased to about one third of the total of US corporate profits and with 55 per cent of this recorded in tax havens, 18 per cent of all US corporate profits are now derived through tax havens. International M\&As more broadly may also be motivated by tax planning (Desai \& Hines, 2002).

Gumpert, Hines \& Schnitzer (2016) use a dataset of German firms to examine whether or not MNEs with operations in high tax countries can benefit from reallocating taxable income to tax havens. They find that only $20.4 \%$ of German MNEs have any tax haven affiliates, potentially because of the cost and difficulty involved. Among German manufacturing firms, a $1 \%$ point higher foreign tax rate is associated with a $2.3 \%$ greater likelihood of owning a tax haven affiliate. This contrasts with earlier evidence of US firms. The relationship is less strong 
for firms in service industries, possibly reflecting the greater difficulty in reallocating taxable service income.

\section{The Location/ Relocation of Intangible assets to Low-Tax Jurisdictions}

A stream of research from the fields of economics, finance and taxation examines the location and relocation of valuable intangible assets to low-tax jurisdictions. Intangible assets (patents, trademarks, intellectual properties, copyrights, etc.) are an increasingly important source of competitiveness for MNEs (Dischinger \& Riedel, 2011; Lipsey, 2007). The fact that they can easily be separated from production locations, combined with the 'public good' nature of some intangible assets means that they are effective as a profit shifting mechanism. Royalty payments are considered a tax-deductible expense in the host country and as additional (taxable) income in the home country (Grubert, 2003a) allowing MNEs to base intangible assets in low tax countries where they can earn a stream of revenue from other group companies either on the basis of licensing or royalties.

Companies with higher levels of intellectual properties (IP) are likely to have more mobile income, facilitating greater scope for profit shifting (Desai et al, 2006; Fuest et al, 2013; Grubert \& Mutti, 2007; Dyreng et al, 2015). The opaque nature of IP makes transfer pricing manipulation both harder to detect and to harder to evaluate. The lack of a functioning external market in many cases makes it difficult to find arms' length prices with which to compare the internal price (Dyreng et al, 2008; Gravelle, 2009; Shackelford, Slemrod \& Sallee, 2011) Work has attempted to evaluate the relationship between tax and IP (Hines, 1999; Grubert, 2003b) as well as the link between IP holdings and the ability to shift profits using datasets of US MNEs (Grubert, 2003b). Other research based on European companies (Dischinger \& Riedel, 2011) confirms the importance of intangible assets and their location for tax planning; finding that the lower a subsidiary's corporate tax rate is relative to other group subsidiaries the 
higher is its level of intangible asset investment. Using a German dataset Overesch \& Schreiber (2009) find that intra-group transfers in firms with higher R\&D intensities are more sensitive to the statutory tax rate. They confirm the importance of $R \& D$ as a mechanism for profit shifting as they find that the tax sensitivity of investments significantly decreases with increases in the R\&D intensity. Karkinsky \& Riedel (2012) use data on corporate patent holdings of European MNEs and find that the location of patents across group affiliates strongly corresponds to tax incentives, with a $1 \%$ increase in the corporate tax rate lowering patent holdings by around 3.5\%. Griffith, Miller \& O'Connell (2014) report similar findings.

There is significant anecdotal evidence about the relocation of intangible assets to low tax jurisdictions (Dischinger \& Riedel, 2011). Pfizer, Bristol-Myers Squibb and Microsoft are all reported to have relocated parts of their R\&D units and patent holdings from their home countries to Ireland. Vodafone's intangible properties are held by an Irish subsidiary and Shell's central brand management is held in a Swiss subsidiary from where other subsidiaries are charged royalties (Dischinger \& Riedel, 2011). Starbucks holds its intangible assets in the Netherlands, reputedly to take advantage of the favourable tax regime there (Financial Times, 2013).

A short case of Starbucks is presented in Box A for illustration purposes. It uses content analysis methodology to analyse the annual reports and disclosure notes of the parent firm based in the US - Starbucks Inc. It also considers the subsidiary, Starbucks EMEA Ltd, based in the UK (full accounts filed with the UK Companies House) and other information from the UK Parliament, House of Commons, Public Accounts Committee. Despite this anecdotal evidence about the importance of IP to tax planning, there is a dearth of research that places IP within the context of the overall strategy of the company both in terms of its operational objectives and its corporate structure. 


\section{Box A}

\subsubsection{Cash Holdings in Foreign Subsidiaries versus Profit Repatriation}

A further tranche of research from the fields of finance, economics and tax has considered the specific effect of the US tax system that encouraged MNEs to leave their profits untaxed outside the US (Azemar, 2010; Brajcich, Friesner \& McPherson, 2013a, b; Grubert \& Mutti, 1991; Grubert \& Mutti, 2000; Louie \& Rousslang, 2008). Zucman (2014) reports that 80 per cent of profits that were recorded in key tax havens were retained there with only 20 per cent being repatriated to the US. Companies such as Apple have been criticised for maintaining their reserves of cash overseas rather than returning it as dividends to shareholders or reinvesting it in the US. As of 2014, Apple reported that \$70billion of earnings were reinvested overseas (Permanently Reinvested Earnings), consequently no tax was payable in the US on these earnings (Apple 2014). This has clear implications for policy makers as well as for shareholders.

Brajcich, Friesner \& McPherson (2013a) adopt a macro approach to examine the issue of repatriations. They find that geographic distance appears to play a significant role, with repatriation significantly more likely from subsidiaries located in Latin and South America, and other nations in the western hemisphere. They conclude that these results are driven by the greater economic integration that exists between the USA and both Canada and Mexico, relative to other nations. This finding may have implications for scholars working on broader location related issues.

Whilst this mechanism has been a key element of tax research, the recent changes introduced by President Trump in the US Jobs and Tax Cuts Act 2017 aimed to reduce its effectiveness as a tax avoidance mechanism. The new tax regime introduced a one-off tax of 15.5 per cent on funds that were not repatriated to the US. The aim of the change was to encourage US 
companies to return up to \$4trillion that is held overseas. Recent research however, estimates that funds repatriated in the first year following the changes are only between $\$ 50$ billion and \$100billion (Davison, 2018).

\subsection{Heterogeneity of Approaches: Firm Characteristics and Tax Avoidance}

\section{Aggressiveness}

It has been noted that MNEs employ a variety of approaches to tax planning (Shackelford \& Shevlin, 2001; Hanlon \& Heitzman, 2010). There is a large body of non-IB research that looks at different aspects of MNEs, and tries to establish the relationship between particular firm characteristics and the aggressiveness to avoid tax. Hanlon and Heitzman (2010) stress the importance of the question "why do some corporations avoid more tax than others?". Similarly, Shackelford \& Shevlin (2001) call for more research on the determinants of tax avoidance aggressiveness. Whilst these calls for research come from the fields of accounting and economics it is clear that they are particularly relevant to those in IB. We argue that understanding what drives MNEs in this area is revealing about their broader strategies. Knowing how decisions are made about tax related issues would also inform research into how other decisions are made within the "black box" of the firm.

\subsubsection{Degree of Multinationality}

Simply being an MNE offers potential for profit shifting. Firms with more overseas subsidiaries or longer value chains appear to have a greater ability to shift profits from high to low tax jurisdictions (Dyreng \& Lindsey, 2009; Grubert \& Mutti, 1991; Rego, 2003). A greater proportion of overseas subsidiaries leads to a more aggressive position being taken on transfer prices (Taylor, Richardson \& Lanis, 2015). Research in this area, however, is becoming increasingly difficult due to a growing trend for US MNEs to reduce the number of subsidiaries disclosed (Donohoe, McGill \& Outslay, 2012). Donohoe et al. (2012) surmise that it may be 
because of the growing interest in tax havens driven by media interest in tax avoidance. They cite Google, which listed 108 subsidiaries in 2009 but only 2 in 2011. This trend towards opacity has continued: in 2015 a new company Alphabet was established as the parent company of Google. It lists only one subsidiary - Google (Alphabet, 2015).

\subsubsection{Size}

Larger MNEs are thought to have the financial and strategic capability to invest in tax planning to enable them to leverage the differences between tax rates and systems in different jurisdictions (Rego, 2003). It is likely that larger MNEs are also more international but results from research looking at the implications of company size for the ETR have been mixed. Some research has found the expected: that larger firms are associated with more tax avoidance, largely through transfer pricing (Benvignati, 1985; Zimmerman, 1985; Lanis \& Richardson, 2015). However, Porcano (1986) finds a negative association and others find no association (Gupta \& Newberry, 1997; Shevlin \& Porter, 1992). The methodologies, sample sizes and ages of these studies vary significantly.

Rego (2003) reveals a complex situation: using a broad sample of US domestic and MNEs she finds higher worldwide ETRs for larger firms. After holding firm size constant, however, she then finds that firms with greater incomes have lower worldwide ETRs. She hypothesizes that larger companies have more opportunities and resources to use to lower their ETR. She also finds that companies with higher pre-tax profits pay a lower ETR than those with lower profits indicating that larger and more successful companies are able to plan their tax affairs more efficiently - experiencing significant economies of scale in relation to their tax avoidance. This is reinforced by her finding that MNEs with more extensive foreign operations have lower worldwide ETRs than firms with fewer overseas operations. This work, however, relied on a single year GAAP ETR measure which as Dyreng et al (2008) point out is not a reliable proxy 
for a longer term (for example, ten year) ETR.

The size of the firm may also have an impact on the decision to locate or relocate. Larger companies with greater absolute tax payments may have a greater incentive to try to reduce these tax bills and may also have a greater ability to bear the costs associated with a move. Desai \& Hines (2002) found that firm size had a positive effect on the company's likelihood to relocate its headquarters.

\subsubsection{Profitability}

Firms with higher levels of absolute profits may have greater incentive to avoid high rates of tax as they have the potential to make greater absolute savings. A series of aggregate level studies consider the link between profitability and corporation tax rates. Whilst it was often assumed that a company would need to generate higher pre-tax profits in higher tax countries to make those operations worthwhile, research has shown that affiliates based in low tax countries tend to record higher pre-tax as well as post-tax profits (Grubert \& Mutti, 1991, Hines \& Rice, 1994; Huizinga \& Laeven, 2008). Rego (2003) finds that firms with higher pre-tax income have lower ETRs suggesting that they avoid more tax than similar firms with relatively lower income. Barrios et al (2012) (using a European sample) determine that the decisions about location for highly profitable subsidiaries are less responsive to host or home country taxation. They hypothesize that this may reflect the location or owner specific rents, in other words, that the firm's FSAs are location bound such that the subsidiary would not be able to make these profits in a different location.

\subsubsection{Top Management Team}

The neoclassical view of the firm which is typically expounded in tax research posits that the same decisions will be made within a firm, regardless of who holds key offices. The individual is treated as homogenous or insignificant, behaving in a rational economic manner and 
responding to the incentives put in place (Bertrand \& Schoar, 2003). However, today's firms are run by groups of individuals (e.g. boards, committees, teams) rather than individuals and the power of group decision making dominates large, or mature corporations. Thus, a growing body of research considers the influence that groups of individuals may play (Bertrand \& Schoar, 2003; Desai \& Dharmapala, 2006; Dyreng, Hanlon \& Maydew, 2010). Dyreng et al (2010) identify a gap in the literature concerning the impact that key executives play in determining the tax strategy of a firm. They find an 11 per cent difference between ETRs when moving between the top and bottom quartile of executives.

Whilst CEOs are unlikely to be tax experts they are able to impact the strategy of the company by "setting the tone" at the top of the organisation. Little research considers the direct relationship between the composition of the board and tax avoidance. Extant research does, however, show a direct relationship between a higher proportion of independent board members and a reduction of tax avoidance (Lanis \& Richardson, 2011). The proportion of female executives may also have some influence on the company's tax planning strategy as female CFOs take more conservative positions in accounting and take less aggressive tax positions than male CFOs (Francis, Hasan, Wu \& Yan, 2014). Female executives also have a greater aversion to corruption and tax evasion (Torgler \& Valev, 2010). It appears clear that individuals can influence what constitutes the tax strategy and potentially strategy more broadly.

\subsubsection{Corporate Social Responsibility}

There is an innate tension between firms maximising returns to shareholders by minimising tax paid and the firm's responsibility to their broader stakeholders and contribution to society through tax payments. The firm's view of its responsibility towards its wider stakeholders is reflected in its position on Corporate Social Responsibility (CSR). Tax can be seen as an ethical issue if MNEs are considered to have at least some degree of flexibility in the tax payments 
that they make. Managers can be considered to be operating in a "moral free space" (Muller \& Kolk, 2015) with discretion about which tax payments they make - in effect having some level of discretion over their ETR. There is research that considers the issue of tax within the area of CSR (Hanlon \& Heitzman, 2010; Lanis \& Richardson, 2012, 2015; Muller \& Kolk, 2015; Campbell \& Helleloid, 2016). Research that does touch on this issue tends to be in the context of developing countries (Bird \& Smucker, 2007; Muller \& Kolk, 2015) and developed countries (Campbell \& Helleloid, 2016). Even research considering the "economic dimensions of corporate social responsibility" (Fontanier \& Kolk, 2007) fails to discuss the corporate tax dimension. The findings from existing research are inconclusive, with some research showing that firms with a greater emphasis on CSR are less likely to avoid tax (Lanis \& Richardson, 2015; Muller \& Kolk, 2015). Others (Davis, Guenther, Krull \& Williams 2016) conversely find that managers and other stakeholders within MNEs do not see the payment of taxes as associated with the CSR performance of a firm.

Because of space constraints, we show some examples of work in our literature review by presenting a summary table of 30 key empirical studies classified by themes in the Appendix 1. It provides detailed information of research objectives, samples, variables, empirical testing techniques and key findings of each of 30 key articles.

\section{SUGGESTIONS FOR FUTURE RESEARCH}

Sections 3.1.1 and 3.1.2 set out work that has been done within IB that is directly relevant to the area. Whilst tax planning has not in itself always been the focus of IB literature there is much that can be applied and can contribute to our knowledge. It is clear that there is significant scope for IB researchers to add to this research stream by recognising the importance of tax planning as a topic and taking a more focused approach. It is hoped that our literature review demonstrates the importance of tax and tax planning to corporate strategy and that this will 
help to stimulate further IB research. Understanding the scope of tax avoidance and the tax avoidance mechanisms used by MNEs are important issues for those who want to gain a comprehensive picture of broader strategy.

\subsection{Theory Development on MNE Corporate Tax Planning}

Tax influences corporate behaviour in some ways that are straightforward but others that are more subtle. It is an issue that cuts across many existing areas of IB research such as location, strategy and corporate governance. Our literature review shows where some of these synergies exist. A stronger theoretical framework is also needed to underpin future research. When empirical factors change significantly the impact of the lack of theory becomes clear. IB research, with its focus on the MNE, can make an important contribution to understanding in this area, particularly in generating a clear view of tax as one element of strategy, how it fits into the overall strategy of the company and what drives the heterogeneity of approaches adopted.

We also recommend that more IB research and theoretical development is needed to improve our understanding of the phenomenon, especially different mechanisms used in tax planning and tax practices adopted by MNEs. Corporate tax is a significant issue for MNEs, affecting operations, strategy, planning and action. Researchers in IB have specialised knowledge of MNEs, however, scholars in other fields including economics, accounting, finance and law do not take an MNE perspective and tend to focus more on empirical work. These scholars outside IB do not tend to be concerned with theoretical development and we therefore suggest that this is the area where IB can make a worthwhile contribution.

4.2. Macro-Level Research on Profit Shifting Estimation and the Effectiveness of Tax Policies 
Our literature review finds clear evidence that MNEs are able to shift profits and that they are increasingly pursuing this strategy. Many organizations, tax authorities, non-governmental organizations (NGOs) and academics have systematically estimated the amount of tax avoidance, such as US\$100-240 billion from the OECD to \$650 billion from the IMF. At this point, it is well accepted that the number is too large and something needs to be done (Dharmapala, 2014). On the other hand, there are studies using micro-level data. For example, Clausing (2016) estimates the effect of profit shifting on corporate tax base erosion for the US, and finds that profit shifting was likely to be costing the US government between $\$ 77$ billion to $\$ 111$ billion in corporate tax revenue, and that these revenue losses have increased substantially in recent years.

Due to differences in profit shifting estimation strategies, however, little is known about the incidence on a global level or how MNEs from different regions operate. Further work that evaluates profit shifting flows at a macro level would increase understanding of global trade and FDI flows.

We argue that understanding the impact of the host and home country's tax rate on trade and FDI flows is vital for policy makers. Growing tax competition, with countries continuously reducing corporate rates and offering other incentives to attract FDI is likely to result in falling government revenues with implications for the distribution of income, the future outflow of profits and have consequent effects for domestic private enterprises and employment. This issue is relevant for both developed and developing countries. Arguably, it is likely to have an even greater impact on developing country governments if they miss out on potential revenues from foreign subsidiaries of MNEs operating within their jurisdictions. More research is vital to understand the operations of MNEs and the implications for policy makers. 
Furthermore, studies on public policies on international collaboration to address tax avoidance are needed. Over 100 countries and jurisdictions are collaborating to implement the OECD's Base Erosion and Profit Shifting (BEPS) measures and tackle BEPS. In a related manner, the 2016 European Union's Common Corporate Tax Base (CCTB) and Common Consolidated Corporate Tax Base (CCCTB) provides for the determination of a single set of rules for calculation of the corporate tax base in the EU. It is important to assess whether these developments will force MNEs to change their behaviour in corporate tax planning in the future.

\subsection{Mechanisms Used in MNE Corporate Tax Planning}

\subsubsection{Transfer Pricing}

Our study finds that much of the literature assumes that regulations relating to transfer pricing are enforced in a homogenous manner, however, due to the varied legislative maturity of the country, or the priority placed on them, the implementation and enforcement may vary. Whilst the OECD Transfer Pricing Guidelines (OECD, 2010) provides for some assistance to tax authorities in less developed countries the lack of resources available for policing transfer prices in these countries is likely to have an impact. We suggest that this provides another variable for the MNE when devising its strategy and another area where research is lacking. Arguably, high levels of enforcement of transfer pricing rules may in turn shift investment to countries with lower taxes and / or enforcement (Azemar, 2010; Bartelsman \& Beetsma, 2003; Chan \& Chow, 1997; UNCTAD, 1999).

\subsubsection{Capital Structure and the Use of Internal Debt}

We suggest that future research from an IB perspective that examines the capital structure of the firm must take into account issues related to tax planning. Intra-firm debt appears to be a particularly important way of adjusting the firm's capital structure to minimise the tax burden. 
Further research is needed to generate a greater understanding of the use of debt and internal debt in particular. A greater understanding of the way that MNEs structure debt within the group, and the operational reasons for its use would facilitate the identification of profit shifting related internal debt.

\subsubsection{Location and Real Economic Activity}

Our review finds that it is clear that corporate tax rates and regimes can significantly influence MNE location decisions. There is a significant body of IB work that focuses on the nature of the location choice, the features of locations, means of investment etc. We suggest that tax incentives, both positive and those that generate the motivation to escape home country location need to be firmly embedded within location-based research. Whilst tax can be researched as a separate, additional issue, it must also be incorporated as a factor that can have a significant impact on MNE behaviour. We recommend that given the recent changes to the US tax code, more up to date research on M\&A and tax structuring is needed to clarify the importance of tax as a motivator in these corporate restructurings.

Furthermore, we suggest that more research is needed to understand not only what tax related factors induce a company to "“escape" but also what factors offered by other countries result in the MNE's move to that country. Work on tax havens has done little to unpick why MNEs choose to locate in one particular haven rather than another. Dunning's theory postulates that MNEs will be attracted to invest because of certain key factors, but when the investment is driven by an "escape" motivation, how will MNEs choose where to locate instead and how do they balance the incentives (secrecy, availability of professional services, tax rates, etc.) offered by these locations? A significant range of factors drives location decisions and the way that tax rates interact with these could be an important topic for IB research and tax. 
On the other hand, there may be other mechanisms related to corporate tax planning that have not been yet investigated in the tax-related literature. One of the potential mechanisms is the use of special purpose vehicles, such as sovereign wealth funds (Murtinu \& Scalera, 2016) and the related taxation (PWC, 2012), which future research could usefully explore.

\subsubsection{The Use of Tax Havens}

The impact of tax on location decisions are exemplified by the extreme cases of inversion and the use of tax havens. Host country location decisions are clearly induced by tax systems, tax rates and the ability of MNEs to shift their profits between locations. The use of the smallest "dot tax havens" in corporate structures can only be part of a tax planning regime. A good understanding of the role of larger countries with attractive markets as well as attractive tax regimes may be harder to establish. Tax havens have a considerable role to play here and research which considers the features of tax havens and the advice given to MNEs would be useful and could contribute to a clear definition of what defines a "tax haven".

\subsubsection{Locations of Holding Intangible Assets}

We find that the host country statutory tax rate becomes less important to firms that have the opportunity to profit shift using the IP and associated royalty payments. We suggest that the growth in importance of IP to MNEs and to digital firms in particular, means that understanding the implications for the location of holding IP assets is key for those working in the field of IB. It is important to enhance our understanding of the role of IP assets within MNE groups. It is suggested that future research could focus on which factors determine where these IP assets are held and which affiliates are involved in their development as well as how transfer pricing decisions in relation to these are made.

\subsubsection{Cash Holdings Versus Repatriation of Earnings}


Our review finds that prior research tends to focus on tax-based explanations of US firms holding cash overseas. The recent changes to the US tax system, however, with the US Tax Cut and Jobs Act passed in 2017, should remove, or at least significantly reduce the incentive for US firms to leave their earnings offshore. Foreign profits will now be taxed the same regardless of whether they are repatriated or not. One potentially fruitful avenue for future research is to focus on non tax-based explanations, such as the use of cash holdings to finance value-creating activities, including the creation or purchases of IP assets.

\subsection{Firm Characteristics and Heterogenity of Approaches in Tax Planning}

\subsubsection{Degree of Multinationality}

Our review shows that the role of geographic diversity is another key area for IB scholars in relation to corporate tax planning. It is important that the scope of future work reaches more broadly - focusing on a wider geographic area including, for example, MNEs from emerging markets that are also aggressive in tax planning, ranging from incorporation in tax havens, FDI into tax havens, and round tripping FDI. Furthermore, future research is recommended to take into consideration the recent significant changes in tax policy and tax rate in 2017 in the US. Once these changes are embedded research that examines the changes US MNEs make in response to these could improve understanding of the way that MNEs respond to tax structures. Furthermore, the OECD's BEPS programme and the EU's CCTB and CCCTB are important events in tax and their effectiveness are yet to be assessed.

\subsubsection{Firm Size and Profitability}

Our review finds that prior research on the relationship between size and MNE profit shifting has produced inconclusive results. It is also unclear whether high profits stimulate tax avoidance or whether a strategy of tax planning increases profits ,at least in low tax locations. We suggest that further empirical research scrutinising the reasons for these results could lead 
to further theoretical development. Work here could also consider the impact of industry and whether firms in specific industries are more likely to increase their profitability through profit shifting.

\subsubsection{Top management team}

We suggest that understanding what drives the level of tax planning and avoidance within individual MNEs is another potential fruitful avenue for future research. Future research is recommended to examine the following research questions: How does the company's attitude to risk or its ethical stance affect the decisions that it makes in its tax planning? How are these decisions made within the MNE?

Research that combines corporate governance with tax planning is required to generate theoretical insight into how companies evaluate the options that they face. How do they evaluate and react to the perceived risk of different strategies. How does corporate governance, corporate culture and the personal ethics of individuals affect the corporate attitude to risk? Future research could focus on the role of individuals including the CEO, COO, CFO, Tax Director and board of directors. Qualitative research, particularly interviews could play a useful role in generating detailed insight into decision making and internal workings of tax planning inside the MNE.

\subsection{Geographic Scope of Research Contexts}

We find that much of the work considered in this review focuses on US companies using quantitative approaches. We argue that the specific nature of the US tax system limits the generalizability of findings to MNEs of other countries. The recent radical changes to this system under President Trump also limit the applicability of historic findings in relation to US MNEs, to future MNE actions. Thus, we emphasize the need for theoretical development: understanding the means by which corporate tax planning strategies are developed in theory 
will enable greater understanding of behaviour whatever the applicable set of tax laws and regulations. We highlight where research has been conducted in a non-US setting and discuss the applicability of findings to different times and situations due to recent developments with the introduction and implementation of new tax agreements and new tax laws.

\subsection{Research Methods}

We suggest that researchers in this area may be required to take a more original and innovative approach to designing their research projects. Researchers must arrive at the phenomenon they want to investigate and then consider the most appropriate research method or combination of methods to advance knowledge. If researchers can access high-quality data which allows them to identify MNEs' reported tax bases, tax liabilities, tax payments and business activity across group locations, traditional quantitative methods with statistical techniques will be appropriate.

Alternatively, qualitative research is appropriate, particularly for research that proposes to generate new understanding of how decisions are made and risk is assessed within companies. Qualitative research methods (e.g. interviews, case studies and consideration of judge's rulings in tax cases) have been used in previous studies in tax and accounting research (Currie, Tuck \& Morell, 2015; Morell and Tuck 2014; Finer \& Ylonen, 2017; James, 2010). Recently, this qualitative research approach has been applied to IB research on MNEs' tax planning (Cooper \& Nguyen, 2019). A comprehensive understanding of how decisions are made in relation to tax would have cross over implications for broader research into strategy and corporate governance.

Published, audited annual reports are another rich source of useful information for IB researchers conducting "content analysis" and "document analysis" (Wright, 2011). These research methods are often neglected in IB research, however, they are frequently used in the accounting and international tax literature (Bewley \& Schneider, 2013; Chen, Su \& Wu, 2010; 
Donohoe et al., 2012; Hageman, Bobek \& Schmitt, 2014; Lanis \& Richardson, 2012). Large databases draw on the information that is included in annual reports but often do not include the totality of data that is published. There is, for example, a great deal of information included within the "Tax Note" in the annual report that is not incorporated into the large databases. This information can be combined with data from the Chairman's reports on the corporate strategy and successes to generate a holistic view of the company and its tax planning activities. Data from annual reports may usefully contribute to case study research or to quantitative statistical analysis. In-depth case study research may be useful to generate the detailed knowledge that is required for generating theory, which is also needed in this area.

The methodology used by Vaitsos (1974) provides a useful example of eclectic research approach and the potential of qualitative financial accounts research. The book contains information on the control of FDI in the Andean Pact countries, and some acute analysis of the MNE phenomenon, especially in Columbia. His analysis on the distribution of the income effects created by the entry of large MNEs into developing countries is allocated between the different participants based on their bargaining abilities and strategies, their ability to manipulate and check various prices and their overall industrialization or global commercial policies.

Lall (1975) notes that Vaitsos (1974) provides a blend of academic work and practical experience rare in this field. According to Lall (1975), most of the people who write with actual experience of MNEs tend to be business school analysts who look at the world very much from the view point of the firms themselves, while most of the academics who write about the general form and effects of MNEs on developing countries tend to have little practical knowledge of how these vast enterprises actually work. Vaitsos straddles both worlds, advising 
the Andean Pact on bargaining and doing research at the IDS in Sussex. His book reflects this useful combination of roles (for a review, see Lall, 1975).

The existing body of evidence cannot indicate how MNEs vary in their tax planning approaches; which will adopt more aggressive tax avoidance measures and which will not. As Hanlon and Heitzman (2010 p.145) conclude: "Overall the field cannot explain the variation in tax avoidance very well...Tax avoidance may be highly idiosyncratic and determined by a number of factors and interactions, not all of which can be measured." Work examining the use of specific mechanisms tends to look at one particular aspect of profit shifting and aims to generate an understanding of the impact that a particular method has on the overall group profit. Firms, however, may use more than one method of profit shifting to reduce their global tax bill. How these methods are combined with each other and the resulting complexity is difficult to ascertain through statistical analysis alone.

\section{CONCLUSIONS}

Our systematic and comprehensive literature review points clearly to the need for IB researchers to engage with MNE's corporate tax planning. It is an issue that cuts across many existing areas of IB research such as location, strategy and corporate governance. Our study also shows where some of these synergies exist. Inter-disciplinary work may be needed to leverage the skills of academics from other areas such as international business, accounting, finance, taxation, law and economics. There have been increasing calls from within other areas for more joined up work (Hanlon \& Heitzman, 2010; Dyreng \& Maydew, 2018). A stronger theoretical framework is also needed to underpin future research to enable IB researchers to make valuable contributions.

Our review has also identified areas where more research is needed. Overall it is clear that the phenomenon of corporate tax planning and profit shifting of the MNE offer considerable scope 
for IB researchers. The lack of easily available quantitative data may create some difficulties for researchers but this is not insurmountable. 


\section{REFERENCES}

Alphabet Annual Report (2015). Available at: https://www.sec.gov/cgi-bin/browseedgar?action=getcompany $\& \mathrm{CIK}=0001652044 \&$ type $=\&$ dateb=\&owner=include $\&$ count $=$ 40 [Accessed 12/2/2018]

Altshuler, R. Grubert, H. \& Newlon, T. (2000). Has US investment abroad become more sensitive to tax rates? In J. Hines, ed., International Taxation and Multinational Activity. Chicago: University of Chicago Press, pp. 9-38.

Altshuler, R. \& Grubert, H. (2002). Taxes, repatriation strategies and multinational financial policy. Journal of Public Economics, 87 (1), pp. 73-107.

Altshuler, R. \& Grubert, H. (2006). Governments and multinational corporations in the race to the bottom. Tax Notes, Vol. 110, No. 8 February 2006.

Aulakh, P. \& Mudambi, R. (2005) Financial resource flows in multinational enterprises: The role of external capital markets. Management International Review. 45 (3) 307 - 325.

Azemar, C. (2010). International corporate taxation and US multinationals' behaviour: an integrated approach. Canadian Journal of Economics, 43 (1), pp 232-253.

Barrios, S. Huizinga, H. Laeven, L. \& Nicodeme, G. (2012). International taxation and multinational firm location decisions. Journal of Public Economics, 96 (11-12), pp. 946-958.

Bartelsman, E. \& Beetsma, R. (2003). Why pay more? Corporate tax avoidance through transfer pricing in OECD countries. Journal of Public Economics, 87, pp. 2225-2252.

Benvignati, A. (1987). Domestic profit advantages of multinational firms. Journal of Business, $3,449-461$.

Bernard, A. Bradford Jenson, J and Schott, P. (2006) Transfer pricing by US based multinational firms. The National Bureau of Economic Research Working Paper 12493. Available at: https://www.nber.org/papers/w12493. [Accessed 13/6/2018]

Bertrand, M \& Schoar, A. (2003). Managing with style: the effect of managers on firm policies. The Quarterly Journal of Economics, 68 (4) 1169-1208.

Bewley, K. \& Schneider, T. (2013) Triple bottom line accounting and energy efficienct retrofits in the social -housing sector: A case study. Accounting and the Public Interest. Vol. 13, No.1, 105-131. 
Bird, F. \& Smucker, J. (2007). The social responsibilities of international firms in developing areas. Journal of Business Ethics, 73 (1), pp 1-9.

Blouin, J. Krull, L. \& Robinson, L. (2012). Is US multinational intra firm dividend policy influence by reporting incentives? The Accounting Review 87 (5), 1463-1491.

Boise, C. \& Koenig, J. (2002). Practical and policy considerations in corporate inversion transactions. Corporate Business Taxation Monthly. September 2002 3-20.

Brajcich, D. Friesner, D. \& McPherson, M. (2013a), Key determinants of repatriated earnings by US multinational enterprises. Multinational Business Review, 21 (3), 269-289.

Brajcich, A. Friesner, D. \& McPherson, M. (2013b). Trends in the shifting of resources by US based multinational companies. Journal of Accounting and Finance, 13(6), pp. 92-106.

Brajcich, A. Friesner, D. \& Schibik, T. (2016) Do US pharmaceutical companies strategically shift income to international affiliates? Multinational Business Review, 24 (1), pp.8-24.

Brinded, L. (2016). Margrethe Vestager explains why Tim Cook is wrong about Apple's huge tax bill. Business Insider (UK). 30 September 2016. Available at: http://uk.businessinsider.com/european-commissioner-for-competition-margrethevestager-on-apple-tax-and-tim-cook-2016-9 [Accessed 5 January 2017].

Buckley, P. \& Casson, M. (1976) The Future of the Multinational Enterprise. Basingstoke and London: Macmillan.

Buettner, T. \& Ruf, M. (2007) Tax incentives and the location of FDI: evidence from a panel of German multinationals. International Tax and Public Finance, 14 (2), pp. 151-164.

Buettner, T. \& Wamser, G. (2013). Internal debt and multinational profit shifting: empirical evidence from firm level panel data. National Tax Journal, 66 (1), pp. 63 - 96.

Buettner, T. Overesch, M. and Wamser, G. (2018) International Tax and Public Finance, 25 $553-580$.

Campbell, K. \& Helleloid, D. (2016). Starbucks: Social responsibility and tax avoidance. Journal of Accounting Education, 37: 38-60.

Casson, M. (1979). Alternatives to the Multinational Enterprise. London: Macmillan 1979. Chan, K. \& Chow, L. (1997) An empirical study of tax audits in China on international transfer pricing. Journal of Accounting and Economics, 23(1), 83-112. 
Chen, C. Su, X. \& Wu, X (2010) Auditor changes following a big 4 merger with a local Chinese firm: A case study. AUDITING: A Journal of Practice \& Theory, 29 (1), pp.41-47.

Clausing, K. (2003) Tax-motivated transfer pricing and US intrafirm trade prices, Journal of Public Economics, 87, 2207-2223.

Clausing, K. (2009). Multinational firm tax avoidance and tax policy. National Tax Journal, 62 (4), 703-725.

Clausing, K. (2016). The effect of profit shifting on the corporate tax base in the United States and beyond. National Tax Journal, 69(4), pp 905-934.

Cobham, A. (2005) Tax avoidance, tax evasion and development finance. Queen Elizabeth House Working Paper Series No. 129. Available at: http://www.sataxguide.co.za/wpcontent/uploads/2015/03/Tax-easion-tax-avoidance-and-development.pdf [Accessed 26/7/2018]

Cobham, A. \& Loretz, S. (2014). International distribution of the corporate tax base: Implications of different apportionment factors under unitary taxation. ICTD Working paper No. 27.

Contractor, F.J. (2016a). Tax avoidance by multinational companies: Methods, policies and ethics. AIB Insights, 16(2): 10-13.

Contractor, F.J. (2016b). Tax avoidance by multinational companies: Methods, policies and ethics. Rutgers Business Review, 1(1): 27-43.

Cooper, M. \& Nguyen, Q. 2019. Understanding the interaction of motivation and opportunity for tax planning inside US multinationals: A qualitative study. Journal of World Business, $54(6)$.

Copithorne, L. (1971) International corporate transfer prices and government policy. Canadian Journal of Economics 4 (3), pp. 324 - 341.

Cristea, A. \& Nguyen, D. (2016) Transfer pricing by multinational firms: New evidence from foreign firm ownerships. American Economic Journal: Economic Policy, 8(3) 170 - 202.

Cuervo-Cazzura, A. Narula, R. and Un, C. (2015) Internationalisation motives: sell more, buy better, upgrade and escape. Multinational Business Review, 23 (1) .25-35.

Cuervo-Cazzura, A. and Narula, R. A set of motives to unite them all? Multinational Business Review, 23(1). 
Currie, G., Tuck, P. \& Morrell, K. (2015). How hybrid managers act as "canny customers" to accelerate policy reform: A case study of regulator-regulatee relationships in the UK's tax agency. Accounting, Auditing \& Accountability Journal, Vol. 28 Issue: 8, 1291-1309.

Davis, A. Guenther, D. Krull, L. \& Williams, B. (2016) Do socially responsible firms pay more taxes? The Accounting Review, 91 (1), 47-68.

Davison, L. (2018) Trump's tax promise of trillions back to US fails to materialize.

Bloomberg, 6 December 2018. Available at:

https://www.bloomberg.com/news/articles/2018-12-06/trump-tax-promise-of-trillions-backto-u-s-fails-to-materialize [Accessed 10/6/2019]

De Mooij, R. \& Ederveen, S. (2006) What a difference does it make? Understanding the empirical literature on taxation and international capital flows, European Commission Economic Papers 261. URL:

https://www.researchgate.net/publication/254413342_What_a_Difference_Does_it_Make_U nderstanding_the_Empirical_Literature_on_Taxation_and_International_Capital_Flows [Accessed 6/3/2018]

Desai, M. Foley, F. \& Hines, J. (2004). A multinational perspective on capital structure choice and internal capital markets. The Journal of Finance, LIX (6), pp. 2451- 2487.

Desai, M. \& Hines, J. (2002). Expectations and expatriations: Tracing the causes and consequences of corporate inversions. National Tax Journal, 55, pp. 409-440.

Desai, M. Foley, F. \& Hines, J. (2006) The demand for tax haven operations. Journal of Public Economics, 90, $513-531$.

Desai, M. \& Dharmapala, D. (2006) Corporate tax avoidance and high-powered incentives. Journal of Financial Economics 79 (1), pp. 145-179

Devereux, M. \& Griffith, R. (2003) Evaluating Tax Policy for Location Decisions International Tax and Public Finance, 10 (2), pp. 107-126.

Devereaux, M. Lockwood, B. \& Redoano, M. (2008) Do countries compete over corporate tax rates? Journal of Public Economics, 92, pp. 1210-1235.

Dharmapala, D. (2014) What Do We Know about Base Erosion and Profit Shifting? A Review of the Empirical Literature. Fiscal Studies, 35 (4) 
Dharmapala, D. \& Riedel, N. (2013) Earnings shocks and tax motivated income shifting? Evidence from European multinationals. Journal of Public Economics, 97, pp. 95-107.

Dischinger, M. \& Riedel, N. (2011) Corporate taxes and the location of intangible assets within multinational firms. Journal of Public Economics, 95, pp. 691- 707.

Donohoe, M. McGill, A. and Outslay, E. (2012) Through a glass darkly: What can we learn about a US multinational corporation's international operations from its financial statement disclosures? National Tax Journal, 65 (4) 961-984.

Dunning, J. (1993). Multinational Enterprises and the Global Economy. Harlow: AddisonWesley.

Durst, M. C. (2016) Self help and altruism: protecting developing countries' tax revenues. In T. Pogge, and K. Mehta, eds, Global Tax Fairness. Oxford: Oxford University Press.

Dyreng, S. Hanlon, M \& Maydew, E. (2008) Long-run corporate tax avoidance, The Accounting Review, 83 (1), pp. 61-82.

Dyreng, S. \& Lindsey, B. (2009). Using financial accounting data to examine the effect of foreign operations located in tax havens and other countries on US multinational firms' tax rates. Journal of Accounting Research, 47 (5), 1283-1316

Dyreng, S. Hanlon, M. \& Maydew, E. (2010). The effects of executives on corporate tax avoidance. The Accounting Review, 85 (4), pp. 1163- 1189.

Dyreng, S. Hanlon, M. Maydew, E. \& Thornock, J. (2017) Changes in corporate effective tax rates over the past 25 years. Journal of Financial Economics. 124 (3)441 - 463.

Dyreng, S. Lindsey, L. Markle, K. \& Shackelford, D. (2015). The effect of tax and non tax country characteristics on the global equity supply chains of US multinationals. Journal of Accounting and Economics, 59, pp. 182-202.

Dyreng, S. \& Maydew, E. (2018) Virtual issue of tax research published in the JAR. Journal of Accounting Research. Available first online at https://doi.org/10.1111/1475-679X.12207 [Accessed 28/3/2018].

Eden, L. (1998). Taxing multinationals: transfer pricing and corporate income taxation in North America. Toronto: University of Toronto Press.

Eden, L. (2003) The internalisation benefits of transfer price manipulation. Bush School Working Paper No. 315. Available at: $\underline{\mathrm{http}: / / \text { citeseerx.ist.psu.edu/viewdoc/download?doi=10.1.1.195.2496\&rep=rep1\&type }=\mathrm{pdf}}$ [Accessed 15/07/2019] 
Eden, L. (2016) The arm's length standard. In T. Pogge and K. Mehta, eds. Global Tax Fairness. Oxford: Oxford University Press.

Eden, L. Valdez, L. \& Li, D. (2005). Transfer pricing penalties and the market valuation of Japanese multinationals in the US. Journal of International Business, 36, pp. 398-414.

Eden, L. \& Kudrle, R. (2005). Tax havens: renegade states in the international tax regime? Law and Policy 27 (1), pp. 100-127.

Egger, P. Eggert, W. Keuschnigg, C. \& Winner, H. (2010) Corporate taxation, debt financing and foreign-plant ownership. European Economic Review, 54 (1), pp. 96 - 107.

Egger, P. Eggert, W. \& Winner, H. (2010) Saving taxes through foreign plant ownership. Journal of International Economics. 81 (1) 99-108.

Financial Times (2013). Dutch deny Starbucks tax deal is secret. 27/3/2013. Available at http://www.ft.com/cms/s/0/b72679f4-96ed-11e2-a77c-

00144feabdc0.html?siteedition=uk\#axzz36mlSxLd6 [Accessed 5/10/2013]

Financial Times (2016). Pfizer to kill \$160bn Allergan merger. 6/4/2016. Available at: https://www.ft.com/content/edb7f406-efbe-37f3-84f2-78ab75f0cb10 [Accessed 28/3/2018]

Financial Times (2019). US corporate cash pile shrinks as spending climbs after tax cuts. Available at https://www.ft.com/content/81ff6034-8b91-11e9-a1c1-51bf8f989972 [Accessed $13 / 6 / 2019]$.

Finer, L. \& Ylönen, M. (2017) Tax-driven wealth chains : A multiple case study of tax avoidance in the finnish mining sector. Critical Perspectives on Accounting. 48 53-81 .

Finke, K., 2013. Tax avoidance of German multinationals and implications for tax revenue: Evidence from a propensity score matching approach. Centre for European Economic Research (ZEW).

Fontanier, F. \& Kolk, A. (2007). On the economic dimensions of corporate social responsibility: exploring fortune global 250 reports. Business and Society, 46, pp. 457-478.

Foss, N. Mudambi, R. \& Murtinu, S. (2019) Taxing the multinational enterprise: On the forced redesign of global value chains and other inefficiencies. Journal of International Business Studies. 50 (9) $1644-1655$.

Francis, B. Hasan, I. Wu, Q. \& Yan. M (2014). Are female CFOs less tax aggressive? Evidence from tax aggressiveness. The Journal of the American Taxation Association, 36 (2), 171-202. 
Fuest, C. Spengel, C. Finke, K. Heckemeyer, J. \& Nusser, H. (2013). Profit shifting and 'aggressive' tax planning by multinational firms: issues and options for reform. Centre for European Economic Research. Discussion paper 13-044. Available at: http://ftp.zew.de/pub/zew-docs/dp/dp13044.pdf [Accessed 28/3/2018]

Fuest, C. \& Riedel, N. (2009) Tax evasion, tax avoidance and expenditures in developing countries: A review of the literature. Working Paper 1012, Oxford University Centre for Business Taxation.

Garcia-Bernado, J. Fichtner, J. Takes, F. \& Heemskerk, E. (2017) Uncovering offshore financial centers: conduits and sinks in the global corporate ownership network. Available at: https://arxiv.org/pdf/1703.03016.pdf [Accessed 13/6/2-19]

Gordon, R. \& Lee, Y. (2001). Do taxes affect corporate debt policy? Evidence from US corporate tax return data. Journal of Public Economics, 82, pp. 195-224.

Graham, J. (2003). Taxes and corporate finance: A review. Review of Financial Studies 16, pp. $1074-1128$.

Galbraith, J.K. (1967). The New Industrial State. Princeton, NJ: Princeton University Press.

Gravelle, J.G. (2009). Tax Havens: international tax avoidance and evasion. National Tax Journal, 62 (4), 727-753.

Griffith, R. Miller, H. \& O’Connell, M. (2014) Ownership of intellectual property and corporate taxation. Journal of Public Economics, 112 (C) 12-23.

Grubert, H. (2003a) The tax burden on cross border investment: company strategies and country responses. US Treasury Department, Centre for Economic Studies and Ifo Instititute) CESifo Working Paper Series No 964. Available at:

http://papers.ssrn.com/sol3/papers.cfm?abstract_id=417348 [Accessed 28/3/2018].

Grubert, H. (2003b). Intangible income, intercompany transactions, income shifting and the choice of location. National Tax Journal, 56(2), pp. 221 - 242.

Grubert, H. \& Mutti, J. (1991). Taxes, tariffs and transfer pricing in multinational corporate decision making. The Review of Economics and Statistics, 73 (2), pp. 285-293.

Grubert, H. \& Mutti, J. (2000). Do taxes influence where US corporations invest? National Tax Journal, 53, pp. 825-40.

Grubert, H. \& Mutti, J. (2007) The effect of taxes on royalties and the migration of intangible assets abroad. NBER Working Paper Series, Working Paper No. 13248. Available at: 
http://www.nber.org/papers/w13248 [Accessed 28/3/2018].

Grubert, H. \& Slemrod, J. (1998). The effect of taxes on investment and income shifting to Puerto Rico. The Review of Economics and Statistics, 80 (3), pp.365-373.

Gumpert, A. Hines, J. \& Schnitzer, M. (2016) Multinational firms and tax havens. The Review of Economics and Statistics, 98 (4) $713-727$.

Gupta, S, \& Newberry, K. (1997). Determinants of the variability in corporate effective tax rates: Evidence from longitudinal data. Journal of Accounting and Public Policy, 16 (1), 1-34. Hageman, A. and Bobek Schmitt, D. (2014) Institutional and Political Antecedents of Interjurisdictional Tax Harmonization: Lessons from Three States. Accounting and the Public Interest. Vol. 14, No. 1, pp. 1-33.

Hanlon, M. \& Heitzman S. (2010). A review of tax research. Journal of Accounting and Economics $50(2 / 3) 127-178$.

Harrington, C. \& Smith, W. (2012). Tax avoidance and corporate capital structure. Journal of Finance and Accountancy, 11, pp. 1-20.

Heckemeyer, J. and Overesch, M. (2017) Multinationals' profit response to tax differentials: Effect size and shifting channels. Candian Journal of Economics. 50 (4) 965 - 994.

Hennart, J. (1982). A Theory of Multinational Enterprise. Ann Arbor, MI: University of Michigan Press.

Hines, J. (1999) Lessons from behavioural responses to international tax. National Tax Journal. 52(2), 305-322.

Hines, J. \& Rice, E. (1994). Fiscal Paradise: foreign tax havens and American Business. Quarterly Journal of Economics, 109, 149 - 182.

Hodge, M. (2016) Called to Account. Great Britain: Little Brown

Horst, T. (1971). The theory of the multinational firm: optimal behaviour under different tariff and tax rates. Journal of Political Economy, 79, 1059-1072.

House of Commons, Public Accounts Committee (2012). Minutes of Evidence. HC716. 12 November 2012. Available at:

https://www.publications.parliament.uk/pa/cm201213/cmselect/cmpubacc/716/121 112.htm [Accessed 3/2/2017]. 
Huizinga, H. \& Laeven, L. (2008) International profit shifting within multinationals: a multi country perspective. Journal of Public Economics, 92 (5-6), 1164 - 1182.

IMF (2018) International Corporate Tax Avoidance: A Review of the Channels, Magnitudes, and Blind Spots. IMF Working Paper 18/168. Available at:

https://www.imf.org/en/Publications/WP/Issues/2018/07/23/International-Corporate-TaxAvoidance-A-Review-of-the-Channels-Effect-Size-and-Blind-Spots-45999 [Accessed $3 / 8 / 2018]$

James, M. (2010) Humpty Dumpty's guide to tax law: Rules, principles and certainty in taxation. Critical Perspectives on Accounting. 21 5(7) 73-583

Jones, C. \& Temouri, Y. (2016). The determinants of tax haven FDI. Journal of World Business, 51, pp. 237-250.

Jones, C. Temouri, Y. \& Cobham, A. (2018). Tax haven networks and the role of the Big 4 accountancy firms. Journal of World Business, 53 (2), pp. 177-193.

Jormanainen, I. \& Koveshnikov, A. (2012) International activities of emerging market firms. Management International Review. $52691-725$.

Karkinsky, T. \& Riedel, N. (2012) Corporate taxation and the choice of patent location within multinational firms. Journal of International Economics, 88 (1) 176 - 185.

Klassen, K. \& LaPlante, S. (2012). Are US multinational corporations becoming more aggressive income shifters? Journal of Accounting Research, 50 (5), pp. 1245-1285.

Kopits, G.F. (1976). Taxation and multinational firm behaviour: A critical survey. Staff Papers (International Monetary Fund), 23(3), pp 624-673.

Lall, S. (1973). Transfer pricing by multinational manufacturing firms. Oxford Bulletin of Economics and Statistics, 35: 173-195.

Lall, S. (1975). Book reviews - Intercountry Income Distribution and Transnational Enterprises. By Constantine V. Vaitsos. (Oxford: Clarendon Press, 1974). World Development, 3 (2-3): 149-152.

Lanis, R. \& Richardson, G. (2011). The effect of board of director composition on corporate tax aggressiveness. Journal of Accounting Public Policy, 30, 50-70.

Lanis, R. \& Richardson, G. (2012). Corporate social responsibility and tax aggressiveness: a test of legitimacy theory. Accounting, Auditing \& Accountability Journal, 26(1), 75-100. 
Lanis, R. \& Richardson, G. (2015). Is corporate social responsibility performance associated with tax avoidance? Journal of Business Ethics, 127, 439-457.

Lessard, D. (1979). Transfer prices, taxes and financial markets: implications of internal financial transfers in the MNE. International Business and Finance, 1 pp.101 -135.

Lewellen, K. \& Robinson, L. Internal Ownership Structures of U.S. Multinational Firms (April 30, 2013). Available at http://dx.doi.org/10.2139/ssrn.2273553 [Accessed 13/4/2019]

Lipsey, R. (2007) Defining and Measuring the Location of FDI Output. NBER Working Paper No.12996. March 2007. Available at: http://www.nber.org/papers/w12996.pdf [Accessed 28/3/2018].

Louie, H. \& Rousslang, D. (2008). Host-country governance, tax treaties and US direct investment abroad. International Tax and Public Finance, 15 (3), 256-273.

Lu, J., Liu, X., Wright, M., \& Filatotchev, I. (2014). The impact of domestic diversification and top management teams on international diversification of Chinese firms. International Business Review, 23(2), 455-467.

Mardan, M. (2017) Why countries differ in thin capitalization rules: The role of financial development. European Economic Review 91, 1-14.

Markle, K. \& Shackelford, D. (2009). Do Multinationals of Domestic Firms Face Higher Effective Tax Rates? NBER Working Paper 15092. Available at:

http://www.etpf.org/papers/41CIT.pdf [Accessed 28/3/2018].

McGaughey, S.L. \& Raimondos, P. J. (2019). Shifting MNE taxation from national to global profits: A radical reform long overdue. Journal of International Business Studies, 50 (9) 1668 $-683$.

Meyer, K. E., Ding, Y., Li, J., \& Zhang, H. (2014). Overcoming distrust: How state-owned enterprises adapt their foreign entries to institutional pressures abroad. Journal of International Business Studies, 45(8): 1005-1028.

Morck, R., Yeung, B., \& Zhao, M. Y. (2008). Perspectives on China's outward foreign direct Investment. Journal of International Business Studies, 39(3), 337-350.

Morrell, K. and Tuck, P. (2014). Governance, tax and folk tales. Accounting, Organisations and Society, 39 (9) 134-147. 
Mudambi, R. (1999) MNE internal capital markets and subsidiary strategic independence. International Business Review. 8 (2) 197-211.

Muller, A. \& Kolk, A. (2015). Responsible tax as corporate social responsibility: the case of multinational enterprises and effective tax in India. Business and Society, 54(4), 435-463

Murtinu, S. \& Scalera, V.G. (2016). Sovereign wealth funds' internationalization strategies: The use of investment vehicles. Journal of International Management, 22 (3), 249-264.

Nebus, J. (2016). Irish-Dutch sandwiches, corporate inversions, and arm's length transactions: international tax for IB courses. Academy of International Business Insights, 16 (2), pp. 14-18. Nebus, J. (2019). Will tax reforms alone solve the tax avoidance and tax haven problems? Journal of International Business Policy, 2(3): 258-271.

Nguyen, Q. T. K. (2013). Can British multinational enterprises finance economic development in South East Asia? Multinational Business Review, 21 (2), pp. 122-147.

Nguyen, Q.T.K. \& Almodovar, P. (2018) Export intensity of foreign subsidiaries of multinational enterprises: the role of trade finance availability. International Business Review, 27 (1), pp. 231-245.

Nguyen, Q.T.K. \& Rugman, A. (2015) Internal equity financing and the performance of multinational subsidiaries in emerging economies. Journal of International Business Studies, 46, pp. 468-490.

Nieckels, L. (1976). Transfer Pricing in Multinational Firms. Stockholm: Almqvist and Wicksell.

OECD (2010) OECD Transfer Pricing Guidelines for Multinational Enterprises and Tax Administrations. Paris: OECD Publishing. Available at: http://www.oecd.org/tax/transferpricing/oecd-transfer-pricing-guidelines-for-multinational-enterprises-and-taxadministrations-20769717.htm [Accessed 13/11/2016].

OECD (2017) Tax planning by multinational firms: firm-level evidence from a cross-country database. Economics Department Working Paper 1355. Available at: https://www.oecd.org/eco/Tax-planning-by-multinational-firms-firm-level-evidence-from-across-country-database.pdf [Accessed 6/6/2017]

OECD (2019). Base Erosion and Profit Shifting (BEPS): International collaboration to end tax avoidance. Available at https://www.oecd.org/tax/beps/ [Accessed 13/6/2019]. 
Overesch, M. \& Schreiber, U. (2009). R\&D Intensities, International Profit Shifting and Investment Decisions. Discussion Paper. Available at:

http://www.socialpolitik.ovgu.de/sozialpolitik_media/papers/Overesch_Michael_uid335_pid 288.pdf [Accessed 28/3/2018].

Oxelheim, L. Randoy, T. and Stonehill, A. (2001). On the treatment of finance specific factors within the OLI paradigm. International Business Review 10 pp. 381-398.

Porcano, T. (1986). Corporate Tax Rates: Progressive, Proportional or Regressive. The Journal of the American Taxation Association, 7, 17-31.

PWC (2012). Sovereign investment funds: Tax considerations for global investors. Available at https://www.pwc.com/jp/en/tax-publications-financial-services/assets/sovereigninvestment-funds-dec2012.pdf [Accessed 17/6/2019].

Rego, S. (2003). Tax avoidance activities of US multinational corporations. Contemporary Accounting Research 20 pp.805-833.

Riedel, N. (2018) Quantifying international tax avoidance: A review of the academic literature. Review of Economics, 69 (2) 169-181

Rugman, A.M. (1980). Internalization theory and corporate international finance. California Management Review, 23(2), 73-79.

Rugman, A. (1981) Inside the Multinationals: The Economics of Internal Markets. New York: Columbia University Press.

Rugman, A. \& Eden, L. eds, Multinationals and Transfer Pricing. London: Croom Helm. Rugman, A.M. \& Collinson, S. (2012). International Business, 6th Edition. Harlow, Essex: Pearson.

Rugman, A.M. \& Verbeke, A., Nguyen, Q.T.K. (2011). Fifty years of international business theory and beyond. Management International Review, 51(6), 755-786.

Samuelson, L. (1982). The multinational firm with arm's length transfer price limits. Journal of International Economics, 13 (3 - 4), 365-374.

Seida, J. \& Wempe, W. (2004). Effective tax rate changes and earnings stripping following corporate inversion. National Tax Journal, 57(4), 805-828.

Servan-Schreiber, J-J. (1967). The American Challenge. Atheneum 
Shackelford, D. Slemrod, J. \& Sallee, J. (2011) Financial reporting, tax and real decisions: towards a unifying framework. International Tax and Public Finance, 18 (4), 461-494.

Shackelford, D. \& Shevlin, T. (2001). Empirical tax research in accounting. Journal of Accounting and Economics, 31, $321-387$.

Shaxson, N. (2011) Treasure Islands. London: Vintage.

Shevlin, T. \& Porter, S. (1992). The corporate tax comeback in 1987: some further evidence. Journal of the American Taxation Association, 14 (1), 58-79.

Schoen, W. (2011) Transfer Pricing - Business Incentives, International Taxation and Corporate Law," Max Planck Institute for Tax Law and Public Finance Working Papers. Available at: https://ideas.repec.org/s/mpi/wpaper.html [Accessed 24/3/2019].

Simon, H. (1957). Models of Man. New York.

Starbucks (2014) Starbucks Annual Report 2014. Available at https://investor.starbucks.com/financial-data/annual-reports/default.aspx [Accessed 12/07/2017]

Starbucks (2017) Starbucks Annual Report 2017. Available at https://investor.starbucks.com/financial-data/annual-reports/default.aspx [Accessed 12/07/2017]

Starbucks (2018) Starbucks Annual Report 2018. Available at https://investor.starbucks.com/financial-data/annual-reports/default.aspx [Accessed 12/07/2019]

Starbucks EMA Ltd. (2017), Report and Financial Statements 2017. Available via Companies House: https://beta.companieshouse.gov.uk/company/09084257/filinghistory [Accessed 31/01/2019]

Starbucks Coffee Company (UK) Ltd (2017) Report and Financial Statements 2017. Available via Companies House: https://beta.companieshouse.gov.uk/company/09084257/filing-history [Accessed $31 / 01 / 2019]$

Strange, R. \& Humphrey, J. (2018). What lies between market and hierarchy? Insights from internalization theory and global value chain theory. Journal of International Business Studies, 1-13. Available at https://doi.org/10.1057/s41267-018-0186-0 [Accessed 13/6/2019]

Strange, R. \& Zucchella, A. (2018). Industry 4.0, global value chains and international 
business. Multinational Business Review, 25(3), pp 174-184.

Suddaby, R. \& Greenwood, R. (2005). Rhetorical strategies of legitimacy. Administrative Science Quarterly, 50(1), pp 35-67.

Sullivan, M.A. (2004). Shifting of profits offshore costs U.S. Treasury $\$ 10$ billion or more. Tax Notes International, 36: 13-17.

Tax Foundation (2013). OECD Tax Rates Over Time. Available at:

http://taxfoundation.org/article/oecd-corporate-income-tax-rates-1981-2013 [Accessed 28/3/2018].

Taylor, G. \& Richardson, G. (2013). The determinants of thinly capitalised tax avoidance structures: evidence from Australian firms. Journal of International Accounting, Auditing and Taxation, 22, pp. 12-25.

Taylor, G. Richardson, G. \& Lanis, R. (2015). Multinationality, tax havens, intangible assets and transfer pricing aggressiveness. Journal of International Accounting Research, 14 (1), pp. $25-57$.

Tax Foundation (2013). OECD Tax Rates Over Time. Available at:

http://taxfoundation.org/article/oecd-corporate-income-tax-rates-1981-2013 [Accessed 13/3/2018].

Torslov, T.R., Wier, L.S. \& Zucman, G. 2018. The missing profits of nations. National Bureau of Economic Research, NBER Working Paper Series, Working paper 24701. Available at https://www.nber.org/papers/w24701 [accessed 8 September 2019]

Ting, A. \& Gray, S.J. (2019). The rise of the digital economy: Rethinking the taxation of multinational enterprises. Journal of International Business Studies, 50 (9) 1656 - 1667

Torgler, B. \& Valev, N. (2010). Gender and public attitudes toward corruption and tax evasion. Contemporary Economic Policy, 28, 554-568.

UNCTAD (1999) World Investment Report 1999: Foreign Direct Investment and the Challenge of Development. Available at: http://unctad.org/en/Docs/wir1999_en.pdf [Accessed 28/3/2018]

UNCTAD (2013) World Investment Report 2013: Global Value Chains. United Nations. Geneva. Available at: http://unctad.org/en/PublicationsLibrary/wir2013_en.pdf [Accessed 13/4/2018]. 
UNCTAD (2016) World Investment Report 2016: Investor Nationality, Policy Challenges.

United Nations, Geneva. Available at:

http://unctad.org/en/pages/PublicationWebflyer.aspx?publicationid=1555 [Accessed $13 / 4 / 2018]$

Vaitsos, C. (1974) Intercountry Income Distribution and Transnational Enterprises. Oxford: Clarendon Press.

van Tulder, R. (2015.) Getting all motives right: a holistic approach to internationalisation motives of companies. Multinational Business Review, 23 (1).

Vernon, R. (1998) In the Hurricane's Eye. London: Harvard University Press.

Voget, J. (2011) Relocation of headquarters and international taxation. Journal of Public Economics, 95, pp. 1067 - 1081.

Wall Street Journal (2006). Glaxo to Settle Tax Dispute With IRS Over US Unit for \$3.4 Billion. Available at: https://www.wsj.com/articles/SB115798715531459461 [Accessed $28 / 3 / 2018]$

Welch, C. Piekkari, R. Plakoyiannaki, E. and Paavilainen-Maentymaeki, E. (2011) Theorising from case studies: Towards a pluralist future for international business research. Journal of International Business Studies 42 (5) 740 - 762.

Weyzig, F. (2013). Tax treaty shopping: Structural determinants of foreign direct investment routed through the Netherlands. International Tax and Public Finance, 20(6), 910-937.

Witt, M. and Lewin, A. (2007). Outward Foreign Direct Investment as Escape Response to Home Country Institutional Constraints. Journal of International Business Studies, 38 (4) 579 594.

Wright, A. (2011) Watch what I do, not what I say: new questions for documents in international business research, in R. Piekkari \& C. Welch eds. (2011). Rethinking the Case Study in International Business and Management Research. Elgar: Cheltenham

Zimmerman, J. (1983) Taxes and Firm Size. Journal of Accounting and Economics, (5), 119149.

Zucman, G. (2014) Taxing across Borders: Tracking Personal Wealth and Corporate Profits. Journal of Economic Perspectives, 28 (4), pp. 121-148

Zucman, G. (2015). The Hidden Wealth of Nations. London: University of Chicago Press 
Economics Book. 